\title{
INTRIIGID, PROVOKATSIOONID JA ISESEISVUSE SÜND: EESTI VÄLISDELEGATSIOON JA AlEKSANDER KESKÜLA
}

\author{
Mart Kuldkepp
}

Kui tekkiva Eesti Vabariigi esimesed välissaadikud 1918. aastal Stockholmi jõudsid, selgus seal nende mitte just rõõmsaks üllatuseks, et Eesti asja ajamisega oli Rootsi pealinnas juba mõnda aega tegeldud - seda aga mitte Maapäeva ja Ajutise Valitsuse volitatud esindajate, vaid kahtlase kuulsusega seikleja ning tõenäolise Saksa agendi Aleksander Kesküla poolt. Visast "ebaesitajast" vabanemine osutus keeruliseks ning järgneva aasta jooksul valmistas Kesküla omavoliline tegevus välisdelegatsioonile omajagu peavalu, kuni ta 1919. aasta kevadel lõpuks silmapiirilt kadus.

Umbes taoline pilt Kesküla ja välisdelegatsiooni kokkupuudetest avaneb esimeste välisesindajate mälestustest ning neile tuginevatest sõdadevahelisel ajal ilmunud standardkäsitlustest. Eduard Laaman nimetab oma "Eesti iseseisvuse sünnis" Kesküla poliitiliseks seiklejaks, kes ühendas endas enamlast ja Saksa agenti ning katsus välisdelegatsiooni oma Eesti büroo rakkesse panna. ${ }^{1}$ Ants Piip "Tormises aastas" jätab Mihkel Martna ja Ferdinand Kulli teadetele toetudes lahtiseks, kas Kesküla oli Saksa agent või lihtsalt hoopleja, kuid märgib, et Gustav Suitsu juhtimisel Stockholmi "Eesti informatsiooni büroo" asutamine osutus vajalikuks just selleks, et "A. Keskküla "Eesti Komiteele" vastukaalu pakkuda. ${ }^{2}$

Praeguseks on mitmeid aspekte Aleksander Kesküla sõjaaegsest tegevusest juba lähemalt uuritud, eriti tema suhteid enamlaste ja Saksa võimudega. ${ }^{3}$ Küllalt hästi on tuntud ka esimese välisdelegatsiooni tegevus

Käesolev artikkel on valminud Rootsi Instituudi (Svenska Institutet, Visbyprogrammet) ja Rootsi kirjanduse Seltsi Soomes (Svenska Litteratursällskapet i Finland, Historiska nämnden) uurimistoetuse abil.

1 Eduard Laaman, Eesti iseseisvuse sünd, teine trükk (Stockholm: Vaba Eesti, 1964), 320-322.

${ }^{2}$ Ants Piip, Tormine aasta: ülevaade Eesti välispoliitika esiajast 1917-1918. aastal dokumentides ja mälestusis (Stockholm: Vaba Eesti, 1966), 4-5, 210.

3 Vt nt Michael Futrell, Northern underground: episodes of Russian revolutionary transport and communications through Scandinavia and Finland, 1863-1917 (London: Faber \& 
Skandinaavias. ${ }^{4}$ Küsimus suhetest Kesküla ja välisdelegatsiooni vahel, millest seni on põgusalt üle libisetud, väärib aga rohkem tähelepanu. Esiteks oli Kesküla välisdelegatsiooni jaoks ebatavaline konkurent - eestlane, kes tegutses põhimõtteliselt sama eesmärgi nimel, mis välisdelegatsioon isegi, kuid keda ei saanud või ei õnnestunud sellegipoolest ühisesse töögruppi värvata. See, millist mõju tal välisdelegatsiooni mittekuulumata õnnestus ikkagi selle tegevusele avaldada, ütleb midagi ka delegatsiooni enda kohta. Teiseks leidsid need sündmused aset Eesti riikluse kujunemise seisukohalt kriitilise tähtsusega perioodil, mil hiljem isegi naeruväärsena näivad intriigid võisid vägagi ohtlikud tunduda.

\section{Eesti esimesed välisesindajad kui proto- ja paradiplomaadid}

Eesti iseseisva riikluse alused kujunesid välja Esimese maailmasõja ja selle järgsete revolutsioonide ning jätkusõdade (sh Eesti Vabadussõda) segasel perioodil, mil Euroopa kui rahvusvahelise süsteemi tulevik oli väga ebakindel. Ent lisaks kõigele halvale, mida valitsev teadmatus kaasa tõi, avas see ka positiivses mõttes seniolematuid võimalusi nii suurriikide hegemoonia- kui ka väikerahvaste autonoomia- ja iseseisvuspüüetele. Mõlemad olid teineteisega tihedalt seotud. Kõik sõdivad suurriigid toetasid separatistlikke liikumisi vaenlase tagalas, et viimast nõrgestada. Samal ajal püüdsid rõhutud rahvaste esindajad suurriikide huvide vahel laveerides keerulist olukorda enda kasuks pöörata. Sõjas, mis lõppes mitme Euroopa impeeriumi lagunemisega ja nõrgestas tõsiselt ülejäänuid, olidki iseseisvusvõimaluse saanud väikerahvad pea ainsate võitjate seas. Ent see sai võimalikuks ainult tänu sellele, et neil jätkus otsusekindlust õigel hetkel tegutseda.

Vabanemisambitsiooni teostamine nõudis väikerahvaste esindajatelt pretsedenditut välispoliitilist aktiivsust. Oma rahva küsimus tuli tuua maailmaareenile, tõstatada seal millegi enama kui impeeriumi siseasjana ning leida liitlasi, kelle huvides oleks separatiste aidata. Neil, kes taolisi samme astusid, ei olnud ega saanudki olla mingit ametlikku volitust, nende tegevus oli salajane ning klassifitseerus vähemalt esialgu riigireetmiseks. See,

Faber Ltd, 1963), 119-151; Olavi Arens, “Aleksander Kesküla”, Eesti Teaduste Akadeemia Toimetised: ühiskonnateadused, 40:1 (1991), 28-37; Kaido Jaanson, "Eestlane Aleksander Kesküla ja Berliin: avang", Tuna, 1 (2004), 12-38; Kaido Jaanson, "Eestlane Aleksander Kesküla ja rahvuste uniooni III konverents Lausanne'is 1916. aastal”, Akadeemia, 9 (2000), 1824-1862; Seppo Zetterberg, Die Liga der Fremdvölker Russlands 1916-1918: ein Beitrag zu Deutschlands antirussischem Propagandakrieg unter den Fremdvölkern Russlands im Ersten Weltkrieg (Helsinki: Finnische Historische Gesellschaft, 1978), 52-58. ${ }^{4}$ Vt nt Laaman, Eesti iseseisvuse sünd; Piip, Tormine aasta; Eero Medijainen, Saadiku saatus: välisministeerium ja saatkonnad 1918-1940 (Tallinn: Eesti Entsüklopeediakirjastus, 1997). 
kuidas neid välismaal vastu võeti, sõltus välisriikide huvidest, nende enda osavusest või ka juhusest, kuid mitte diplomaatilisest protokollist. Kui arengud kodumaal või vastuvõtvas riigis olid soodsad, sai osa neist esialgsetest esindustest siiski pikkamööda mingi ametliku staatuse. Tavaliselt toimus see pärast seda, kui kodumaal oli tekkinud institutsioon, mida võis pidada vastava rahvusgrupi esinduseks ning mis seetõttu sai väljastada oma esindajatele ametlikke volitusi.

Ka Eesti rahva väliesindajate jaoks oli aeg enne Eesti riikluse de jure tunnustamist igas mõttes väga ebakindel. Võttes aluseks Ernest Satow’ klassikalise definitsiooni, mille järgi "diplomaatia on mõistuse ja takti rakendamine iseseisvate riikide valitsuste vahelistes ametlikes suhetes, mis mõnikord laieneb ka nende suhetele vasallriikidega"5, on 1918. aasta algul välismaale jõudnud Eesti välisdelegatsiooni liikmete diplomaatideks nimetamine väga küsitav. ${ }^{6}$ Veelgi kohatum oleks nõnda tituleerida seal juba varem Eesti iseseisvuse heaks tegutsenud isikuid, nagu Aleksander Kesküla. See, et mõlemad püüdsid oma eesmärkide saavutamiseks rakendada "mõistust ja takti" (mitte sõjalist jõudu), on muidugi väljaspool kahtlust, kuid iseseisva riigi valitsuse ametlikud esindajad ei olnud nad rangelt võttes kumbki.

Eriti selge on lugu Aleksander Keskülaga, kellel puudus Eesti rahva välisriikides esindamiseks tõesti igasugune mandaat. Ennast iseseisvaks välispoliitikuks pidav Kesküla võis sellest puudujäägist küll mööda vaadata, kuid tõsiasja, et tal oli Eestis ka ükskõik millise muu mõõdupuu järgi sama palju sidemeid ja mõju "[...] nagu Sandwichi saartel", 7 ei saanud ta siiski lõputult ignoreerida.

Ent ka Maapäeva volitusega välisdelegatsioonil tuli alles välja võidelda enda tunnustamine Eesti rahva õiguspärase ja usaldusväärse esindusena ning muud "ebaesitajad" diskrediteerida. Kumbki ülesanne polnud kerge. Olukorras, kus Eesti riiki polnud ükski teine riik de jure tunnustanud, maal valitses Saksa okupatsioon ja ainsaks autoriteetseks institutsiooniks, millele võis tugineda, oli laiali saadetud Maapäev, oli välisesindusel õiguslikke probleeme enam kui küll. Sellele lisandusid isiklikud ja maailmavaatelised vastuolud, volituste puudulikkus, sidepidamisraskused Eestiga, rahapuudus ning vastutöötamine teiste jõudude ja isikute poolt, kelle seas Kesküla oma Eesti olude hea tundmise ja suurepäraste kontaktidega nii Saksamaal kui ka Entente’i maades kujutas tõsiseltvõetavat ohtu.

${ }_{5}$ Ernest Satow, A guide to diplomatic practice, 3rd edn. (London: Longmans, 1932), 1.

${ }^{6}$ Rahvusvahelise õiguse järgi võis Eesti esindajaid diplomaatilisteks agentideks nimetada alles alates 1921. a jaanuarist, vt Medijainen, Saadiku saatus, 17.

7 Riigiarhiiv [edaspidi ERA], f.1621, n. 1, s. 123, 1. 6-7, Kodumaalt saadetud teated. 
Satow' mõttes diplomaatia mõiste asemel oleks välisdelegatsiooni ja Kesküla tegevuse iseloomustamiseks asjakohasemad protodiplomaatia ja paradiplomaatia mõisted. Neist esimest määratles mõiste esmakasutaja Ivo D. Duchacek kui võimaliku suveräänse riigi separatistlikku tegevust, mille käigus mingi olemasolev kohalik autoriteet saadab välismaale omapoolse missiooni (või kasutab olemasolevaid kontakte), et seal tulevasele riiklusele pinda ette valmistada. Soovi korral võib välisriik neid "protosaatkondi" ja "protokonsulaate" ajutiste diplomaatiliste esindustena tunnistada, kuid pole selleks muidugi kohustatud. ${ }^{8}$ Seega sisaldub protodiplomaatia mõistes teatav ametlik legitimeeritus (tegemist peab olema autoriteetse initsiatiiviga), nagu ka suunatus tulevikku (iseseisvale riiklusele). Tulemuseks on tegelikult anakronism, kuna mõiste on kasutatav ainult tagantjärele tarkusest, et nimetatud autoriteet tõesti osutus autoriteetseks ning protodiplomaatiale järgnes ka päris-diplomaatia.

Sellegipoolest on mõiste vähemalt selle artikli raames heuristilise kategooriana kasutuskõlblik, kuna iseloomustab Eesti välisdelegatsiooni tegevust suhteliselt täpselt. Lisaks viib provintsiaalsest autoriteedist Maapäevast ja tema välisesindusest suveräänse Eesti Vabariigi ja tema välisteenistuseni vägagi sirge joon. Ainult ühest esimese välisdelegatsiooni liikmest ei saanud karjääridiplomaati või riigimeest ning seegi erand - Ferdinand Kull - visati delegatsioonist oma kolleegide poolt välja juba selle tegutsemisajal.

Paradiplomaatia mõiste on üldisema tähendusega. Duchacek tarvitab seda selliste rahvusvaheliste suhete kohta, mis pole suunatud suveräänse riigi loomisele, vaid on peamiselt seotud majanduslike, ühiskondlike ja kultuuriliste küsimustega. ${ }^{9}$ Iñaki Aguirre laiendab sõna tähendusvälja hõlmamaks igasuguste mitteametlike (st valitsuse või muu keskse autoriteedi poolt volitamata) toimijate diplomaatiataolist tegevust, mis vastab James Der Deriani abstraktsele definitsioonile diplomaatiast kui vahendamistegevusest (mediation) üksteise suhtes võõrandunud (estranged / alienated) sfääride vahel. Taoliste toimijate seas võivad olla nii rahvusvahelise haardega ettevõtted ja organisatsioonid kui ka näiteks silmapaistvad indiviidid. ${ }^{10}$

\footnotetext{
8 Territorial dimension of politics: within, among, and across nations (Boulder and London: Westview Press, 1986), 248.

9 Ivo D. Duchacek, "Multicommunal and bicommunal polities and their international relations", Perforated sovereignties and international relations: trans-sovereign contacts of subnational governments, ed. by Ivo D. Duchacek, Daniel Latouche and Garth Stevenson (New York and London: Greenwood Press, 1988), 22.

10 Iñaki Aguirre, "Making sense of paradiplomacy? An intertextual enquiry about a concept in search of a definition", Regional \& Federal Studies, 9:1 (1999), 196-197.
} 
Minu soov Aleksander Kesküla püüdlusi viimatimainitud tähenduses paradiplomaatilisteks nimetada põhineb esiteks veendumusel, et tegemist oli silmapaistva isikuga. Teiseks vastab tema maailmasõja-aegne tegevus, ehkki täiesti omavoliline, vähemalt diplomaatia välistele tunnustele, kui neid Der Deriani kombel piisavalt avaralt mõista. ${ }^{11}$ Kesküla ei olnud mitte pelgalt Saksa agent ega tühipaljas hoopleja, milles teda kahtlustati, vaid tõepoolest iseseisev poliitik, kes sarnaselt välisdelegatsiooniga püüdis keerulist rahvusvahelist olukorda ära kasutada oma poliitiliste sihtide saavutamiseks - seejuures küll vaevumata oma eesmärkide või taktika õigsuse üle kellegi teisega nõu pidama.

Käesoleva artikli eesmärk ei saa olla proto- ja paradiplomaatia mõistete rakendusvõimaluste põhjalik analüüs, rääkimata nende ühemõttelisest defineerimisest. See vääriks kindlasti omaette põhjalikku käsitlust. Järgnevas kasutan ma neid üksnes käepäraste tööriistadena, et avada konkreetselt Eesti välisdelegatsiooni ja Kesküla suhete problemaatikat, pretendeerimata mõistete päris samal kujul asjakohasusele laiemalt või muudes kontekstides. ${ }^{12}$ Võib-olla tuleb Eesti juhtumi eripärana eraldi rõhutada, kuivõrd suurel määral on taolise eristuse näol tegemist postfaktuaalse konstruktsiooniga, sest 1918. aastal oli Eesti riiklus veel äärmiselt esialgne. Ehkki tänapäeval levinuima nn deklaratiivse riigiteooria kohaselt saaks riiki pidada õigussubjektiks juba juhul, kui see faktiliselt täidab riigiks olemise eeldusi (kindlaks määratud territoorium, püsiv rahvastik, toimiv valitsus ja võime teiste riikidega suhteid luua) ning teiste riikide tunnustus ei ole tingimata vajalik, ${ }^{13}$ pole puhtdeklaratiivne riiklus ilmselt ka praeguses maailmas suuremat väärt. 1918. aasta oludes, kui isegi nimetatud faktilised eeldused suuresti puudusid, sai Eesti riik olla parimal juhul tulevikulubadus, reaalselt aga pigem unistus. See, et nimetatud unistus täitus ja seda pealegi variandis, mille eellooks sai Maapäeva ja välisdelegatsiooni tegevus, võib tagasivaates tunduda loomulik, kuid omaaegsel välismaalasest diplomaadil pidi olema pea võimatu seda mingigi kindlusega ette näha. Seetõttu tuli nii proto- kui ka paradiplomaatidel nii avalikkuse ees kui ka kuluaarides

\footnotetext{
11 Der Deriani mõistestiku kohta vt James Der Derian, "Mediating estrangement: a theory of diplomacy", Review of International Studies, 13:2 (1987), 91-110 ja James Der Derian, On diplomacy: a genealogy of Western engagement (Oxford: Blackwell, 1987).

12 Näiteks saaks teistel samasse ajajärku puutuvatel juhtudel rääkida lausa "postdiplomaatiast" (endiste Vene diplomaatide tegevus aastatel 1917-22/24). Käesolevas artiklis ei käsitleta lähemalt ka baltisakslaste Stockholmi esinduse (Baltische Landesvertretung) tegevust, mida võiks samuti paigutada paradiplomaatia mõiste alla. 13 Vt nt William Thomas Worster, "Law, politics and the conception of the state in state recognition theory", Boston University International Law Journal, 27:1 (2009), 119.
} 
teha pingutusi, et jätta endast mulje kui paljulubavast protoesindusest ning vastaspool ummikteele viiva paranähtusena diskrediteerida.

See ei tähenda, et neil oleksid puudunud erinevused omas ajas. Eesti välisdelegatsioonil, erinevalt Keskülast, olid olemas Maapäeva kui Eesti rahva õiguspärase esinduse volitused, mis andsid kogu nende tegevusele ametlikkuse oreooli ning välistasid Kesküla-taoliste mandaadita üksiküritajatega lähematesse suhetesse astumise. Samas peitus ametlikkuses ka nõrkus, kuivõrd seda oli võimalik mitmest suunast kahtluse alla seada. Kesküla, kes suhtus välisdelegatsiooni pretensioonikatesse amatööridesse ilmse üleolekuga, ei jätnud neid võimalusi kasutamata. Ühenduses teiste mõjuritega viis see kokkuvõttes esimese välisdelegatsiooni lagunemiseni.

Käesoleva artikli eesmärk on näidata, kuidas kujunesid kontaktid Eesti esimeste protodiplomaatide ja kuulsaima paradiplomaadi vahel ning püüda hinnata, kuivõrd Keskülal õnnestus mõjutada välisdelegatsiooni tegevust ja eriti selle sisepingeid. Ma ei püüa seejuures väita, et Kesküla tegevus oli nimetatud sisekonfliktide ainus või peamine põhjus. Küll aga näib mulle, et välisdelegatsiooni avatus ilma igasuguse volituseta eraisiku intriigidele iseloomustab hästi seda, millises keerulises olukorras Eesti esimesed välissaadikud end leidsid. Seega tuleks käesolevat juhtumiuuringut võtta eeskätt ainult ühe aspektina laiemast probleemikompleksist. Mis puutub Keskülasse, siis allikate nappuse või kättesaamatuse tõttu pole õnnestunud kõiki oletusi lõpuni kontrollida, kuid loodetavasti osutub see võimalikuks tulevikus. Sel juhul moodustab käesolev ülevaade baasi, millelt on võimalik edasi liikuda.

Valdavas osas põhineb käsitlus Eesti arhiivimaterjalidel. Võttes arvesse nii artikli mahtu kui ka läbiuuritud materjalide laadi on lähtutud eeskätt välisdelegatsiooni perspektiivist: neile teadmata fakte on mainitud vaid erandjuhul. Samasugune käsitlus Kesküla vaatenurgast vajab veel kirjutamist.

\section{Eesti Maapäeva protodiplomaatilise tegevuse algus}

1917. aasta hilissuvel taasalanud Saksa vägede pealetung ning Riia hõivamine 3. septembril ${ }^{14}$ sundisid vaid mõni kuu tagasi autonoomia saavutanud Eesti poliitikuid tõsiselt arvestama Saksa okupatsiooni ohuga. Sellega seoses väljendas Jaan Tõnisson 7. septembril Maapäeva kinnisel istungil esimest korda ametlikku initsiatiivi luua rahvuslikest huvidest lähtuv Eesti välispoliitika, mille eesmärk oleks Eesti eraldumine Venemaast ning samas

$\overline{14}$ Artiklis kasutatud kuupäevad on antud uue kalendri järgi. 
hoidumine Saksamaa võimu alla sattumast. Selleks tuli Tõnissoni arvates Läänemere-äärsetel väikerahvastel omavahel liituda ja suurvõimude vastuolusid ühisel jõul ära kasutada, et kujundada oma territooriumist Entente'i ja Saksamaa huvisfääride vaheline puhvertsoon, mille kõik liikmed võiksid poliitilise iseseisvuseni jõuda. Programmi teostamine nõudis aga "aktiivseks hakkamist" ja "välispoliitika tegemist" teiste rahvaste ja riikide juures. ${ }^{15}$

Protodiplomaatilisele algatusele iseloomulikult põhines Tõnissoni kavatsus Eesti küsimust maailmaareenile viia "meie rahva" huvidel ja sellest tuleneval suhteliselt mitteformaalsel välispoliitilisel aktivismil, mitte aga plaanil kuidagi ära kasutada "sisemiselt surmani haige" Vene riigi välissuhtlust, mida võinuks traditsioonilise diplomaatiamõiste alla liigitada. Ainsad autoriteedid taolise välispoliitika taga said olla Maapäev ja Maavalitsus, nende taga omakorda Eesti rahvas, tulevikulootusena ka Asutav Kogu. Kõigele lisaks oli tegutsemisega kiire, mis ei jätnud võimalust olude selginemist oodata: "Kui meie kui rahvas omariikluse ideaali täideviimiseks mitte ei suuda nüüdset momenti kasulikult tarvitada, siis ei tea, millal võiks veel parem silmapilk tulla."16

Tõnissoni ettepanek iseseisvuse saavutamise strateegia osas ei leidnud erilist toetust: Balti-Skandinaavia liidu asemel pidas enamik sõnavõtnuid tõenäolisemaks siiski Vene föderatsiooni teket. Samas polnud ka nemad välisesinduse loomise vastu. Kui Tõnisson pani hääletusele ettepaneku, et Maanõukogu nimetaks ametisse isikud "kelle ülesandeks on väljapool kodumaad meie rahvusliste huvide kaitseks välja astuda", võeti see vastu ainult ühe vastuhäälega. ${ }^{17}$

Saksa okupatsiooni ei tulnud kaua oodata: 12. oktoobril algas dessantoperatsioon Eesti saarte hõivamiseks. Kuna Maanõukogu tundis nüüd endal olevat õigust "kaasa rääkida Vene sõjalistes küsimustes meie maal", astuti ka esimene välispoliitiline samm: 29. oktoobril esitas Ants Piip Maanõukogu liikmena ning Maanõukogu esimehe suulisel volitusel Briti, Prantsuse, Ameerika ja Belgia saadikutele Peterburis protestinoodi Vene sõjaväe laastava tegevuse vastu Eestis. ${ }^{18}$

Samal ajal loodi Tallinnas ja Peterburis komiteed ühenduse pidamiseks okupeeritud saartega, ${ }^{19}$ mis muuhulgas püüdsid ära kasutada olemasolevaid kontakte välismaaga, sh ilmselt ka Aleksander Keskülaga. Okupeeritud saarte Tallinna komitee liikme ja eestirootslaste rahvusliku

\footnotetext{
${ }^{15}$ Piip, Tormine aasta, 12.

${ }^{16}$ Ibid., 12, 15.

${ }^{17}$ Ibid., 13-17.

${ }^{18}$ Ibid., 20-22.

${ }^{19}$ Ibid., 23.
} 
liikumise juhi Hans Pöhli paberite seas on säilinud rootsi haridustegelasele Gideon Danellile Uppsalasse saadetud telegrammi tekst, milles Pöhl palub abi leidmaks sobivat isikut, kes võiks tegutseda kullerina okupeeritud Saaremaa ja Stockholmi vahel. Danell pidi selles küsimuses võtma ühendust Oskar Elevandiga Stockholmis. ${ }^{20}$ Viimane tegutses teadupärast Kesküla erasekretärina.

Eesti iseseisvuse ideed asus sellal avalikult propageerima Helsingis elav Gustav Suits. Kontaktis Soome iseseisvusmeelsete ringkondadega oli ta 1917. aasta sügisel "juba omandanud Venemaast lahtilööva, ent muidugi mitte ka Saksaga ühendusse jääva vaatenurga”. Selle asemel soovitas Suits Soome-Eesti "neutraalsete vaheriikide" uniooni kui lahendust, mis pidanuks ära hoidma Saksa võimu põlistumise Eesti üle. Kodumaal peeti Suitsu ideid nii kodanlike kui ka sotsiaaldemokraatlike ringkondade poolt esialgu eluvõõraks. Avalike vastukirjutajate seas oli näiteks Mihkel Martna. ${ }^{21}$

Eestis oli samal ajal järjekindlalt kasvanud toetus enamlastele. 4. novembril asutati Peterburi võimuhaaramise eeskujul ka Tallinnas Eestimaa Sõja-Revolutsioonikomitee, mis viis päeva hiljem kubermangukomissar Jaan Poskalt võimu üle võttis. 26. novembril teatasid enamlased, et Maapäev saadetakse kahe päeva pärast laiali. Vastusena kuulutas Maapäev end 28. novembril 1917 kõrgeimaks võimuks Eestis, laiendas juhatuse ja vanematekogu võimupiire ning otsustas kokku kutsuda Asutava Kogu. ${ }^{22}$ Ants Piibu sõnul võib sellest sellest hetkest peale "kõnelda Eesti riigist kui tegurist rahvusvahelises elus, kelle status esialgu märkimata, kelle sihtki esialgu ei ole küllalt välja kujunenud, kuid kes on oma kübara visanud rahvaste võitluse areenile" ning "algab juba Eesti tegelik välispoliitika." ${ }^{23}$ Kuivõrd ennatlik selline hinnang riigiõiguslikus mõttes ka ei oleks, võib Piibuga selles mõttes nõustuda, et Maapäeva välispoliitiline tegevus muutus tõepoolest aktiivsemaks, ehkki Maanõukogu ise juba samal päeval, 28. novembril, enamlaste poolt tõesti laiali aeti.

Vanematekogu 30. novembri otsusega sai Ants Piip 3. detsembril asjuri (chargé d'affaires plenipotentaire) volituse. Samalaadne otsus tehti ka enamlaste kätte vangi langenud Jaan Tõnissoni kohta, kes vabakspääsemise tingimusena oli andnud nõusoleku Eestist lahkuda. ${ }^{24}$ Tõnisson siirduski

20 Riksarkivet [edaspidi RA], Hans Pöhls arkiv, vol. 11.

${ }^{21}$ Gustav Suits, “Tagasivaade Eesti Vabariigi sünniaegadele”, Tulimuld, 1-2 (1973), 32. Martna vastukirjutist Suitsule vt Postimees, 30.11.1917.

22 Vt Seppo Zetterberg, Eesti ajalugu (Tallinn: Tänapäev, 2009), 382.

23 Piip, Tormine aasta, 29.

24 Ibid., 59-6o. Kalervo Hovi, Die Orientierung der estnischen Auslandsdelegation im Frühjahr 1918 (Turku: Institute of General History, University of Turku, 1973), 60; 
pärast vabanemist 8. detsembril kohe Helsingisse, kus jõudis aastavahetuse paiku pidada läbirääkimisi äsjaiseseisvunud Soome senati juhi Pehr Evind Svinhufvudiga. Pahempoolsete (kuid mitte ainult) ringkondadega Helsingis suhtlesid samal ajal ka sotsiaaldemokraat Mihkel Martna ja esseeridega ühinenud Gustav Suits. ${ }^{25}$ Viimane oli üheaegselt Piibu ja Tõnissoniga saanud Jaan Raamotilt ettepaneku välisesindaja ametisse astumiseks, mille ta küll esialgu tagasi lükkas. ${ }^{26}$

Pärast Eestimaa rüütelkonna 13. detsembri otsust Venemaast lahkulöömise kohta püüdis okupeeritud saarte komitee liikmete delegatsioon võtta 30. detsembril ühendust Saksa saadikuga Peterburis, et uurida võimalusi Eesti Ajutise Valitsuse tunnustamiseks Saksamaa poolt. Samal ajal ilmus Peterburi eestikeelses ajalehes Eesti Maapäeva välispoliitilise aktivismi apoloogia, Ants Piibu artikkel pealkirjaga "Eesti välispoliitika", milles autor rõhutas, et välispoliitika pole mitte "diplomatide või üksikute äravalitute asi" vaid "puudutab igat kodanikku" ja peab kõigi eestlaste seas tulema "sarnaselt päevakorrale, kui teised põlevad päevaküsimused." 27 Peterburi ülikooli rahvusvahelise õiguse eradotsendi Piibu seisukohalt oli keskvõimu poolt sanktsioneerimata välispoliitiline tegevus seega õiguspärane, kuna välispoliitika pidi kuuluma rahvale samavõrd kui teised poliitilise elu valdkonnad.

Rahva poliitilisi vaateid esindavad erakonnad jäid kuni detsembri lõpuni üldiselt truuks Venemaa föderaalriigi ideele, arvates, et enamlaste võim kaua ei kesta. Iseseisvuse taotlemises leppisid vanematekogu ja parteide esindajad kokku alles 13. ja 14. jaanuaril 1918. Sellekohane märgukiri ilmus 24. jaanuaril ajalehes Eesti. Sama kuupäevaga on dateeritud Ferdinand Kulli ja Karl Robert Pusta poolt Jaan Poska juhatuse all koostatud "Memorandum Eesti poliitilise seisukorra üle", mis taotles välisriikidelt Eesti iseseisvuspüüdluste toetamist. ${ }^{28}$

Eduard Laaman, "Välisdelegatsiooni aeg”, Jaan Tõnisson töös ja võitluses: koguteos tema seitsmekümnenda sünnipäeva puhul, toim Hans Kruus jt (Tartu: Koguteose "Jaan Tõnisson" komitee, 1938), 203.

25 Piip, Tormine aasta, 61-70.

26 Suits, "Tagasivaade Eesti Vabariigi sünniaegadele", 36; Riigiarhiiv [edaspidi ERA], f. 957, n. 18, s. 31, 1. 92, Suits Poskale 29.4.1918.

27 Piip, Tormine aasta, 37-40, 77.

28 Suits, "Tagasivaade Eesti Vabariigi sünniaegadele", 25; Piip, Tormine aasta, 78-80, 82-85, 96. Laamani arvates mängis iseseisvusmõtte aktuaalseks muutumisel otsustavat rolli Eestimaa rüütelkonna peamehe Eduard Julius Alexander Dellingshauseni ettepanek Eesti poliitikutele, et nad okupatsioonivägede kutsumisest osa võtaks: Eduard Laaman, "Meie välispoliitika viperused 1918 a. Märkusi F. Kulli mälestuste juurde", Vaba Maa, 1.5.1932. 
Samal päeval kirjutati välja volitused välisdelegatsioonile, mis pidi tegelema memorandumi levitamisega. Sinna kuulusid lisaks varem värvatud Piibule ja Tõnissonile ka Ferdinand Kull, Mihkel Martna, Karl Robert Pusta ja Eduard Virgo. Memorandumitele ja volitustele kirjutasid alla Maanõukogu nimel Jüri Jaakson ning Maavalitsuse esimehena Konstantin Päts. Volitused olid ainult paarirealised ja sisaldasid lakoonilist teadaannet, et vastav isik on Maanõukogu volitatud diplomaatiline esindaja (agent diplomatique). Välja jagati ka sihtkohad: Martna ja Menning määrati Saksamaale, Tõnisson Skandinaaviasse, Pusta ja Kull Pariisi ning Piip Londonisse. Virgo pidi jääma sidemeheks. ${ }^{29}$ Tuleb rõhutada, et volitused olid sisult kõigi jaoks võrdsed ning välisdelegatsiooni liikmete tulevasi alluvusvahekordi neis kindlaks ei määratud.

"Tormise aasta" trükivariandis märgib Piip, et saadikutele ei antud üleüldse mingeid erilisi juhtnööre: nende ülesanne oli memorandum ära anda ja saadud vastustega tagasi tulla. ${ }^{30}$ Käsikirjalises mustandis lisab ta siiski, et delegaadid pidid välisriikide juures ette valmistama pinda Eesti iseseisvuse tunnustamiseks, milleks tuli siirduda Skandinaaviasse kui neutraalsesse piirkonda, kus oli võimalik suhelda kõigi riikidega. Ühtlasi tuli Saksamaa kaudu seada jalule ühendus saartega ja eriti sondeerida pinda Balti-Skandinaavia liidu küsimuses, seda kuni kitsama ühenduseni "vana hea Rootsiga" protektoraadi või konföderatsiooni kujul. Arvati, et "Rootsile võiks teatud moodul kõdistav olla" ja aitaks Eestis Vene meelevalla alt pääseda. Vormilist tunnustamist esialgu nõuda ei tulnud, jäädes ootama Asutava Kogu kokkutulekut. ${ }^{31}$

Välisdelegatsioon alustas tegevust kiiresti. Pärast Venemaa Asutava Kogu laialisaatmist käisid selle eestlastest liikmed Jaan Poska, Jüri Vilms ja Julius Seljamaa 23.-26. jaanuaril eraviisiliselt Peterburi Briti, Ameerika ja Prantsuse saatkondades uurimas, kuidas suhtuvad Entente'i maad Saksamaa ettepanekusse Eesti iseseisvumiseks Saksa kaitse all (eestlased ise eelistavat föderaliseerunud Venemaa koosseisu jääda). ${ }^{32}$ Kaks nädalat hiljem olid ühes Seljamaaga samades saatkondades Piip ja Virgo, kes avaldasid taas muret, et Saksa intriigid ja bolševike vägivallateod võivad kallutada eestlaste sümpaatiat Saksamaa poole. Saadud julgustavad vastused, sh Suurbritannia esindaja kaudu saadud lubadus Eesti iseseisvuspüüdlusi

\footnotetext{
${ }_{29}$ Piip, Tormine aasta, 99; Suits, “Tagasivaade Eesti Vabariigi sünniaegadele”, 36; Hovi, Die Orientierung der estnischen Auslandsdelegation, 60.

30 Piip, Tormine aasta, 99.

31 ERA, f. 1624, n. 1, s. 101, Ants Piip, “Tormise aasta" mustand, 12.

32 Hovi, Die Orientierung der estnischen Auslandsdelegation, 61.
} 
rahukonverentsil toetada, andsid vähemalt Piibu väitel julgust tegutseda resoluutsemalt Eesti Vabariigi väljakuulutamisel. ${ }^{33}$

Eesti esimese välisesinduse tegevuse legitiimsus põhines esiteks põhimõttelisel seisukohal, mida Ants Piip väljendas ka oma artiklis, et välispoliitika on kogu rahva asi ning, teiseks ja konkreetsemalt, Eesti Maapäevalt kui Eesti rahva tahet esindavalt autoriteetselt institutsioonilt saadud volitusel. Sellega on olnud päri ka hilisemad ajaloolased. Näiteks Olavi Arens, vastates küsimusele "Kust tuli Eesti riigivõim?" toob välja de facto tunnustamise "kahe Antandi riigi poolt, samuti Soome ja osalt muidugi ka Saksamaa poolt", nagu ka selle, et "[u]ue riigi võim kasvas välja rahva poolt valitud Maapäevast ja toetusest, mida talle andsid Eesti poliitilised parteid, sõjaväeüksused ja Eesti ühiskond" ${ }^{34}$ Kuna ajaliselt järgnes esimene faktor teisele, sai Eesti esimeste välissaadikute enda õiguspärasuse allikaks sai olla ainult Eesti Maapäev ise oma autoriteediga.

\section{Mida teadis välisdelegatsioon Aleksander Keskülast?}

Olulise tausta järgnevate sündmuste mõistmiseks moodustab see, mida välisdelegatsioon Keskülast teadis, või vähemalt mille teadmist võis neilt eeldada. Praegused ajaloolased on Kesküla tegevusest muidugi märksa paremini informeeritud, kuid siinses ülevaates lähtun infost, mille pinnal eeldatavasti kujunes välisdelegatsiooni suhtumine konkurenti.

Aleksander Kesküla kuulsus eestlaste seas pärines 1905. aasta revolutsiooni päevilt ning oli seotud rea värvikate sündmustega. 1904. aastal, kui oli alanud Vene-Jaapani sõda, võeti noor, 1882. aastal sündinud Kesküla tööle ajalehte Postimees sõjatelegrammide toimetajaks. Peatselt sattus ta aga konflikti peatoimetaja Jaan Tõnissoniga, mis päädis Tõnissonile esitatud (ja viimase poolt tagasi lükatud) duellikutse ning Kesküla väljaviskamisega EÜS-ist. Võib-olla kättemaksuks organiseeris Kesküla samal sügisel Postimehe trükikojas sotsiaaldemokraatliku ringi ning pole võimatu, et just konflikt Tõnissoniga põhjustas Kesküla lõpliku kaldumise sotsialismi

\footnotetext{
${ }^{33}$ Piip, Tormine aasta, 95-96. Samas jäid iseseisvuse kõrval jätkuvalt päevakorda ka võimalikud alternatiivsed arenguteed (Eesti-Soome võimalik liit, laiem Balti-Skandinaavia ühendus, autonoomia tulevases Vene föderatsioonis jne). See nähtub näiteks Piibu septembri algusel kirjutatud kirjast Pustale: vt Eero Medijainen, "Ants Piip Eesti kohast rahvusvahelistes liitudes, 1918", Kleio, 9 (1994), 37-41. Liiduplaanide kohta põhjalikumalt vt Marko Lehti, A Baltic league as a construct of the new Europe: envisioning a Baltic region and small state sovereignty in the aftermath of the First World War (Frankfurt am Main: Peter Lang, 1999).

34 Olavi Arens, "Riik võim ja legitiimsus Eestis aastatel 1917-1920", Acta Historica Tallinnensia, II (2007), 78.
} 
poole. Kesküla õe Elvi sõnul jäi tema vend Tõnissoni vihkama elu lõpuni. Kesküla tundnud Juan Linz väitis samas, et Tõnisson olnud ainus Eesti poliitik, kellesse Kesküla suhtus teatava austusega. ${ }^{35}$

1905. aasta alguses asus Kesküla Tallinnasse ning osales seal VSDTP-le orienteeritud Tallinna komitee loomisel. 9. juulil organisatsiooni tuumik arreteeriti, sh Kesküla, kes vabanes koos teistega alles 15. oktoobril. Pärast vabanemist muutusid Tallinna komiteed juhtima asunud Kesküla nõudmised järjest äärmuslikumateks, sh. nõudis ta töölistele relvade jagamist ja avalikke väljaastumisi. Umbes sel ajal hakkas ta end nimetama enamlaseks, seda pea ainsana eesti n-ö intelligentide seast. ${ }^{36}$

Kui seltsimeeste varasemad mälestused Keskülast on pigem positiivsed - Marta Lepa järgi oli 1905. aasta alguse Kesküla "veel niisama sümpaatne idealist, ekspansiivne unistaja ja romantik" - siis pärast vangist vabanemist hakanud tema juures ilmnema "diktaatorlikud kalduvused" ${ }^{37}$ Rudolf Vakman, Paul Pinna ja Karl Ast kirjeldavad Kesküla kui revolutsionääraadlimeest, kes vaatamata radikaalsetele vaadetele oli ääretult uhke ja enesekeskne. Alma Ostra-Oinase meelest polnud Kesküla üldse õige revolutsionäär, vaid "avantürist, õnneotsija", kelle hingeelus etendanud tähtsat osa vaen Tõnissoni vastu. ${ }^{38}$ Mihkel Martna märgib, et Kesküla suutis taluda vaid endale täiesti ustavaid alluvaid. ${ }^{39}$

Tekkis muidki pingeid. Tallinna komitees surus Kesküla läbi plaani alustada korjandust üldstreigi organiseerimiseks. Oktoobris ja novembris korjandus toimuski, kuid niivõrd hooletul moel, et Kesküla süüdistati osa raha omistamises. Novembri lõpus osales ta Tartus nn aulakoosolekul, kus nõudis sõjalist vastuhakku keskvõimule. Selleks ajaks olid Kesküla

\footnotetext{
35 Heinrich Erits, Endel Kuusik, "Aleksander Kesküla inimese ja revolutsionäärina kaasaegsete mälestustes”, Ajalooline Ajakiri, 3/4 (1999), 50; Rootsi Töölisliikumise Arhiiv (Arbetarrörelsens arkiv) [edaspidi ARA], Undersökningskommissionen Alfred Kruses handlingar, Martna Buhharinile, dateerimata; Ajalooarhiiv [edaspidi EAA], f. 5377, n. 1, s. 65, "Kesküla elu kronoloogia, märkmed", 11-13.

36 Eduard Laaman, Enamlus Eestis I (Tallinn: Kaitsevägede Staabi VI os., 1930), 30. Kaido Jaanson, "Algus ehk see nõndanimetatud Esimene vene revolutsioon. Skits", Tuna, 1 (2005), 49, 54; Ferdinand Kull, Mässumehi ja boheemlasi: mälestusi 1905. aasta revolutsionääridest, vanglatest ja Pariisi Eesti boheemkonnast (Tallinn: Eesti Päevaleht, Akadeemia, 2010), 11.

${ }^{37}$ Marta Lepp, 1905. aasta romantika, järellained, lõppvaatus (Tallinn: Eesti Päevaleht, Akadeemia, 2010), 30.

${ }^{38}$ Vakmani, Pinna, Asti ja Ostra-Oinase arvamusi vt: Jaanson, "Algus ehk see nõndanimetatud Esimene vene revolutsioon", 46-49, 54.

${ }^{39}$ ARA, Undersökningskommissionen Alfred Kruses handlingar, Martna Buhharinile, dateerimata.
} 
grandioossed plaanid relvade ja raha hankimiseks teeninud talle välja hüüdnime Aleksander Suur. ${ }^{40}$

Kui 10. detsembril 1905 kehtestati sõjaseisukord, arreteeriti suurem osa Tallinna komitee liikmetest, ent mitte Kesküla. Järgmisel päeval toimus Volta vabriku keldris suur tööliste miiting, kus Kesküla oli üks organiseerijatest. Mitmed kohalviibinutest mäletavad, et just tema kutsus üles mõisaid põletama ning mõisnikele kätte maksma. Ent kui Volta koosolek laiali aeti, õnnestus Keskülal jällegi napilt pääseda. Kuna teised kaks samal viisil pääsenut paljastati hiljem politsei agentidena, jäi ka temale kahtlusvari. ${ }^{41}$

Jõulude paiku kadus tagaotsitav Kesküla Tallinnast ning asus looma kontakte revolutsiooniliste liikumiste vahel Tartus, Peterburis ja Riias, millele järgnes VSDTP Põhja-Liivimaa organisatsiooni asutamine 1906. aasta oktoobris Tartus. Komiteed asutati ka teistes kohalikes linnades. Aprillis Põhja-Liivimaa organisatsiooni liikmed arreteeriti, ennast Tartu observatooriumis varjanud Keskülal aga õnnestus pääseda ning 1907. aasta mais lahkus ta Terijoele Soome. Taas kahtlustati, et Kesküla oli olnud provokaator.

1908. aasta sügisel astus Kesküla Moskva ülikooli, kus käis kuni 1909. aasta detsembrini, mil talle Tallinnas koos Jaan Teemandi ja terve hulga teistega esitati tagaselja sõjaväekohtu süüdistus paragrahvi järgi, mis nägi karistuseks ette 4-8 aastat sunnitööd. Kesküla süüasja arutamine jäi aga protsessist välja, kuna ta jõudis Venemaalt põgeneda, siirdudes Saksamaale, kust ta 1910. aastal läks edasi Šveitsi. ${ }^{42}$

Kuni pagulusaastate alguseni mainitakse Keskülaga seotud seiku 1905. aasta revolutsionääride mälestustes küllalt tihti ning tõenäoliselt olid need sündmused hästi teada ka välisdelegatsiooni liikmetele. Viimaste seast olid lisaks Tõnissonile Keskülaga isiklikult kokku puutunud vähemalt Ferdinand Kull ja Mihkel Martna. Kull oli isegi arreteeritud ja hiljem süüdi mõistetud Kesküla käest Terijoel saadud kompromiteeriva kirja pärast, mille tõttu ta pidi kaks ja pool aastat vanglas ja hiljem seitse aastat poliitilise pagulasena Pariisis veetma. ${ }^{43}$

\footnotetext{
${ }^{40}$ Erits, Kuusik, "Aleksander Kesküla inimese ja revolutsionäärina", 52; Jaanson, "Algus ehk see nõndanimetatud Esimene vene revolutsioon", 59-61, 67.

${ }^{41}$ Kaido Jaanson, "Mis juhtus 1905. a. 11. (24.) detsembri õhtul Voltas? Katse rekonstrueerida minevikku", Tuna, 4 (2005), 44-48.

42 Jaanson, "Algus ehk see nõndanimetatud Esimene vene revolutsioon", 64, 68-70, 73-77; Aleksander Looring, "Noor Tuglas punaseil aastail”, Looming, 3 (1936), 295-296.

${ }^{43}$ Kullile kui "algajale sotsialistile" oli Keskülale iseloomulik salapärasus sügavat muljet avaldanud. Viimati puutus Kull Keskülaga kokku veel Berliinis, vahetult enne Kesküla lahkumist Šveitsi, vt Kull, Mässumehi ja boheemlasi, 11, 24, 45, 63-64.
} 
Mis puutub Kesküla tegevusse pärast Eestist lahkumist, siis näib, et sellest teati vähe. Ilmselt kõige paremini informeeritud oli Mihkel Martna, kes oli samal ajal Keskülaga olnud poliitiline pagulane Saksamaal ja hiljem Šveitsis. Kesküla sõjaaegsetest tegemistest teadis aga Martnagi ainult kuulduste järgi.

1916. aasta suvel saadetud kirjas Buhharinile kirjutab Martna, et Kesküla oli 1911. aasta paiku asutanud Šveitsis "Eesti sotsiaaldemokraatlike emigrantide seltsi", millel oli ainult 3-6 liiget. Teistega tülli läinud Kesküla jäi sinna lõpuks üksi, kuid sellele vaatamata kasutas seltsi nime, dokumente ja pitsatit edasi. Kesküla "seiklushimuliseks, kuid siiski ausaks inimeseks" pidanud Martna ei uskunud talle Eestis osaks saanud kahtlustusi, kuid pidas fiktiivse seltsi juhtumit murettekitavaks ja arvas, et Kesküla oli seltsi kasutanud selleks, et oma tegemistele usutavamat tausta anda. Lisaks oli ta tähele pannud, et Kesküla elas märkimisväärselt jõukalt, eriti alates 1915. aasta kevadest. Sama aasta suvel oli Martna kuulnud, et Kesküla on siirdunud Stockholmi, kus elab seitsmetoalises villas ja konspireerib eesmärgiga luua iseseisvat eestlaste riiki või põhjamaist föderatsiooni. Fiktiivse seltsi inventari oli ta lahkudes andnud üle teisele eestlasele, enamlaste hulka kuuluvale Arthur Siefeldile. 1915. aasta sügisel protesteeris Martna Zürichi Vene seltsis selle vastu, et Kesküla fiktiivse seltsi nimel üles astub, mille peale olevat Siefeld organisatsiooni paberid ja templi Vene seltsile üle andnud. ${ }^{44}$ See vahejuhtum oli tõenäoliselt üks põhjustest, miks Kesküla Martna vastu rõhutatud vastumeelsust tundis.

Lisaks oli Martna teadlik Kesküla osavõtust "Saksa kindralstaabi rahadega toime pandud" "Lausanne'i väikerahvaste konverentsist" 1916. aasta suvel, kus Kesküla oli avaldanud mõtteid Eesti iseseisvuse teemal. Oma selleaegses päevikusissekandes nimetab Martna teda otsesõnu Saksa agendiks, kes tegutsevat Eesti iseseisvuse nimel ainult selleks, et jätta sakslastele muljet, nagu võiks ta seeläbi Vene võimudele raskusi valmistada. ${ }^{45}$ Teistele inimestele Šveitsis oli Kesküla samas väitnud, et on enamlaste välispropagandaosakonna sekretär - ehkki, nagu Martna oli järele uurinud, Lenin teda praktiliselt ei tundnud. 1915. aastal oli Kesküla kohtunud Kopenhaagenis Eduard Vildega ja teinud talle ettepaneku Venemaal

${ }^{44}$ ARA, Undersökningskommissionen Alfred Kruses handlingar, Martna Buhharinile, dateerimata; Mihkel Martna, "Katkendid päevaraamatust. Ilmasõda", Mälestused iseseisvuse võitluspäevilt, I köide: revolutsioon ja okupatsioon 1917-1918, Eesti Ajakirjanikkude Liidu toimetusel (Tallinn: Rahvaülikool, 1927), 36-37; ERA, f. 2124, n. 2, s. 321, 1. 159, Martna Kullile, suvi 1918 (dateerimata).

45 Martna, "Katkendid päevaraamatust. Ilmasõda", 36-37. 
allaandmismeeleolusid levitama hakata ning sotsiaaldemokraat August Lossmanile pannud ette Saksamaale sõjaasjandust õppima minna. ${ }^{46}$

\section{Välisdelegatsiooni tegevus Stockholmis kuni 1918. aasta maikuuni}

Välisdelegatsioon alustas Stockholmis tööd 1918. aasta 25. jaanuaril, kui sinna jõudis Jaan Tõnisson, kes järgnevaks pooleteiseks kuuks jäigi Rootsi pealinna üksi. 4. veebruaril koostas Tõnisson omal initsiatiivil märgukirja, milles protesteeris Eesti- ja Liivimaa rüütelkondade iseseisvusdeklaratsiooni vastu ning kinnitas, et Maapäev, ainus eestlasi esindav institutsioon, oli 28. novembril 1917 Eesti juba iseseisvaks kuulutanud. Seejärel esitas ta selle kirjutise sõdivate riikide - Nõukogude Venemaa ja Skandinaavia maade saadikutele. Lisaks selgitas ta Suurbritannia saadikule Esme Howardile suuliselt, et Maapäev loodab tulevasel rahukonverentsil eriti Suurbritannia toetusele ning kirjeldas majanduslikku kasu, mida britid Eesti iseseisvusest võiks saada. Nii Howardile kui Prantsuse saadik Thiébaut'le jättis Tõnisson positiivse mulje ning viimane soovitas välisminister Pichonil eestlaste taotlusi toetada. ${ }^{47}$ On märkimisväärne, et Thiébaut, kes oli varasemas telegrammis Prantsuse välisministeeriumile Tõnissoni esialgu "Saksa emissariks" pidanud, muutis temaga kohtumise järel oma arvamust. 5. veebruaril kirjutatud uues kirjas nimetab ta rüütelkondade iseseisvusdeklaratsiooni vastu protesteerivat Tõnissoni "Liivimaa ja Eestimaa rõhuva enamuse" tunnete esindajaks, keda tasuks kuulda võtta. ${ }^{48}$

5. veebruaril viis Tõnisson oma kirjutise ka Saksa saadik Luciusele ning rääkis talle, et enamik eestlasi taotleb garanteeritud neutraliteeti Šveitsi eeskujul ning soovib igal juhul Venemaast lahku lüüa. Tõnisson pidas tulevasele Eestile vajalikuks Saksa kultuurilist orientatsiooni ja majandussidemeid Saksamaaga ning selgitas, et eestlaste saksavaenulikkus on suunatud baltisakslaste, mitte aga Saksamaa enda vastu. Tõnisson pidas võimalikuks ka liitu Eesti ja saksasõbraliku Soome vahel ning tõrjus otsustavalt tagasi süüdistuse eestlaste ühekülgsest orienteeritusest Suurbritanniale. Taolisel mõttel polevat Eestis mingit kõlapinda ning juba geograafilise vahemaa tõttu olevat Briti orientatsioon illusoorne. Asjaolu, et ta oli ka Entente'i

46 ERA, f. 2124, n. 2, s. 321, 1. 159-16o, Martna Kullile, suvi 1918 (dateerimata).

47 Hovi, Die Orientierung der estnischen Auslandsdelegation, 63-64. Esme Howardi ja tema Balti-sõbraliku tegevuse kohta neil aastail, eriti aga Pariisi rahukonverentsi ajal vt B. J. C McKercher, Esme Howard: a diplomatic biography (Cambridge: Cambridge University Press, 1989).

48 Thiébaut Pichonile 5.2.1918, Jaan Tõnisson Eesti välispoliitikas 1917-1920: dokumente ja materjale, toim Heino Arumäe (Tallinn: Jaan Tõnissoni instituudi kirjastus, 1993), 60. 
maade saatkondadesse pöördunud, seletas Tõnisson neutraliteedipüüdlustest tuleneva erapooletuse ning vajadusega täita Maapäeva direktiive. ${ }^{49}$

Sarnaselt Entente'i saadikutega oli ka Luciuse ja sel ajal Stockholmi saatkonnasekretärina tegutsenud Kurt Riezleri arvamus Tõnissonist positiivne ning nad püüdsid Auswärtiges Amt'i veenda Eesti neutraliseerimisplaanidega nõustuma. Ent Berliinis pääses peatselt võimule baltisaksa lobitöö, Maapäeva saadikuid Saksamaale ei lubatud ja igasugune sisuline võimalus Eesti orientatsiooniks Saksamaale jäi kasutamata. ${ }^{50}$

Üheaegselt saatkondades käimisega lõi Tõnisson kontaktid ka poolametlikus sfääris, kuhu kuulusid teised temasarnased: vabanemisambitsioonidega rahvaste para- ja protodiplomaatilised esindajad. Üks võtmeisikuid neis ringkondades oli Soome aktivistide välisdelegatsiooni juht Herman Gummerus, kellega Kesküla oli eestlaste huvide esindajana lävinud juba alates 1915. aasta sügisest. Gummerus, kes nimetati 1918. aasta veebruari algul nõunikuks Soome saatkonna juurde Stockholmis ja kes hiljem, sama aasta märtsikuus, vahendas Eesti välisdelegatsiooni püüdeid oma esindajaid Saksamaale läkitada ${ }^{51}$ kohtus Tõnissoniga juba 4. veebruaril. Samal päeval oma baltisakslasest kaastöölisele Friedrich von der Roppile läkitatud kirjas kirjutab Gummerus, et ka talle oli Tõnisson jätnud hea ja ausa mulje. Kesküla suhtes, kellega Tõnisson oli kohtunud päev varem, olevat eestlane olnud skeptiliselt meelestatud. ${ }^{52}$ Teadetes järgnevatest plaanide kohta, mida Gummerus ja Tõnisson pidasid Soome, Eesti ja Ukraina ühiseks apelliks bolševistliku Venemaa vastu, Kesküla nime enam ei mainita. ${ }^{53}$

Pärast seda, kui Brest-Litovski rahuläbirääkimised olid katkenud ning Saksa pealetung Eesti maismaal alanud, astus Tõnisson resoluutsemalt välja Eesti iseseisvuse eest. 21. veebruaril teatas ta Esme Howardile, et lähiajal on oodata Asutava Kogu kokkukutsumist ja iseseisvusdeklaratsiooni, samas Howardit informeerides, et kui Suurbritannia Eesti iseseisvust ka

49 Jaan Tõnisson Eesti välispoliitikas, 67-69. Põhjalikku käsitlust Eesti-Soome liidu küsimusest neil aastatel vt Seppo Zetterberg, Suomi ja Viro 1917-1919: poliittiset suhteet syksystä 1917 reunavaltiopolitiikan alkuun (Helsinki: Suomen Historiallinen Seura, 1977).

${ }^{50}$ Kurt Riezler pidas 1918. aasta jaanuaris ja veebruaris sidet ka Keskülaga, kuid usaldas Tõnissoni rohkem. Samuti oli Riezler juba 1918. aasta jaanuaris välisminister Kühlmannile tungivalt soovitanud, et Saksamaa tunnistaks Eesti iseseisvaks vabariigiks, (vt Olavi Arens, "Aleksander Kesküla", Eesti Teaduste Akadeemia Toimetised: ühiskonnateadused, 40:1 (1991), 35). Välisdelegatsiooni katsete kohta Saksamaale pääseda ja baltisaksa vaatepunkti esilekerkimise kohta Berliinis vt lähemalt: Arved von Taube, "Das Auswärtige Amt und die Estnische Frage 1917/1918”, Jahrbücher für Geschichte Osteuropas, 4 (1969).

${ }^{51}$ Vt Soome Riigiarhiiv [edaspidi SRA] 602:220, H. Gummeruksen kokoelma, k. 51, Martna Gummerusele, Tõnisson Gummerusele, Menning Gummerusele, 27.3.1918.

${ }^{52}$ Ibid., Gummerus Roppile, 4.2.1918.

${ }^{53}$ Ibid., 10.2.1918; 18.2.1918, 6.3.1918. 
lõplikult ei tunnusta, oleks eestlaste vastupanu seisukohalt väga oluline, kui Asutavat Kogu tunnustataks vähemalt ajutiselt de facto. Nii Suurbritannia kui eriti Prantsusmaa esindaja Stockholmis pidasid sellist Saksamaa vastu suunatud žesti soovitavaks ning vastavalt 1. ja 20. märtsil tunnustasid Prantsusmaa ja Suurbritannia valitsused Eesti Asutavat Kogu de facto iseseisvana kuni rahukonverentsini. ${ }^{54}$

12. märtsil jõudsid Stockholmi Piip, Pusta, Virgo, Martna ja Menning, kellest esimesed kolm umbes nädala pärast teed jätkasid. Tänu neile saadi 3. ja 13. mail vastavalt Suurbritannialt ja Prantsusmaalt uued de facto tunnustused Maapäevale (eelmine tunnustus kehtis Asutavale Kogule, mis kokku ei tulnudki). 29. mail järgnes ka Itaalia oma. Piip ja Pusta jäid seejärel Londonisse ja Pariisi, kuid Virgo pöördus Roomast tagasi Skandinaaviasse. Samal ajal püüdsid Martna ja Menning saada sissepääsuluba Saksamaale ning asusid aprillikuus koos Tõnissoniga ümber Kopenhaagenisse. ${ }^{55}$

Välisdelegatsiooni Entente'i orientatsioon nende kuude vältel pigem süvenes. 22. aprillil Suurbritannia välisministeeriumile saadetud kirjutises teatavad delegatsiooni liikmed, et orienteeritus Saksamaale või saksasõbralikule Soomele on eestlaste jaoks välistatud ning rahva enamus soovib täielikku suveräänsust ja hindab kõrgelt Inglismaalt saadud tunnustust. Sarnaste avaldustega esines Londonis ka Piip. Samas hoiduti sulgemast juurdepääsu Keskriikidele. Aprilli alguses kinnitas Tõnisson Saksa saadikule Kopenhaagenis taas, et ta pole mingil juhul britisõbralikult meelestatud. Vastupidi, Saksamaa olulisust mõistetavat Eestis väga hästi, mistõttu on oluline, et Martna ja Menning Berliini pääseksid. Martna omakorda väitis Austria-Ungari saadikule, et eestlaste eesmärk on luua erapooletu vabakaubandusriik, mis oleks lähedastes suhtes Keskriikidega. ${ }^{56}$

Kuigi näib tõenäoline, et tegelikult asetas välisdelegatsioon suuremaid lootusi Entente'i riikidele - nagu Tõnisson neid väljendas juba oma Maapäeva kõnes - arvestati samas kindlasti ka Saksamaa jätkuva suurvõimurolliga ning püüti baltisaksa anneksioonipoliitikale selles raamistikus vastu töötada. Samas andis taoline laveerimine Saksamaa ja Entente'i huvide vahel kergesti alust kahtlustusteks vastavalt kas Entente'i- või Saksa-sõbralikkuses. Tundlikust orientatsiooniküsimusest tulenev ettevaatlikkus süvendas omakorda välisdelegatsiooni passiivsust, mida Laaman pidas hiljem kogu varase Eesti välispoliitika suurimaks paheks. ${ }^{57}$

\footnotetext{
${ }^{54}$ Hovi, Die Orientierung der estnischen Auslandsdelegation, 65.

${ }^{55}$ Ibid., 70-71.

${ }^{56}$ Ibid., 71-72.

${ }^{57}$ Laaman, "Meie välispoliitika viperused 1918 a. Märkusi F. Kulli mälestuste juurde”.
} 


\section{Jaan Tõnissoni ja Ferdinand Kulli kohtumised Aleksander Keskülaga}

Asjaosaliste mälestustes leidub mitmeid vihjeid, et Tõnisson ja Kesküla pidid olema kohtunud. Ferdinand Kull jutustab, et soovides Kesküla "kauaaegset väljamaa elu ja kogemusi ära kasutada" oli Tõnisson ta üles otsinud ja vaatamata varasematele kokkupõrgetele läbirääkimisi alustanud, mis aga katkesid, "sest Kesküla nõudis ei vähem ega rohkem, kui et Eesti välisdelegatsioon "Eesti büroo" diplomaatilisel juhendamisel töötama peaks" ${ }^{58}$ Sama kinnitab ka Eduard Laaman, kelle järgi oli üks Tõnissoni esimestest pikematest raportitest teinud erilist lõbu, kuna seal oli humoorikalt jutustatud "kohtamisest ühe Eesti nõnda-ütelda diplomaatilise esindajaga, kellest meil seni aimugi polnud olnud. Selleks oli tuttav 1905. aasta tegelane Aleksander Keskküla." ${ }^{59}$

Raport, mida Laaman ilmselt silmas peab, on 1918. aasta 18. veebruariga dateeritud pikk käsikirjaline ülevaade, milles on kohtumisest põhjalikult juttu. Selle järgi oli Tõnisson juba Soomes kuulnud, et Keskülal on Stockholmis mingi "teate-büroo", ülesandega välismaal Eesti huvisid kaitsta. Soovides kõiki olemasolevaid jõude ära kasutada, otsis Tõnisson Kesküla peatselt pärast saabumist üles. ${ }^{60}$ Tõenäoliselt toimus nende esmakohtumine 2. või 3. veebruaril, ${ }^{61}$ st veel enne Tõnissoni visiite saatkondadesse.

Tõnisson juhtus Keskülale külla tulema hetkel, mil tema juures viibis soome aktivist "kellele A. Keskküla Eesti küsimust nii ütelda Suur-Eesti mõtteviisi seisukohalt valgustas". Seejärel jäid eestlased omavahele ning Kesküla seletas Tõnissonile, et "Soome aktivistid olevat üleüldse kõik "kaabakad", kes päälegi Saksa teenistuses seisvat, oma hinge põhjas Eesti vastu vaenulikud ja ka Soome vabaduse mõtte salajased vastased, kuna nemad Soome kui ka Eesti rahvuslise mõtte tõusust Rootsi asjale kahju kartvat jne". Tõnisson kirjutab, et nende süüdistustega jättis Kesküla talle kohe halva mulje. ${ }^{62}$

Ometi oli Keskülal kõige otsesemas mõttes õigus. Nimetatud Soome aktivist, kelle vestlusele Keskülaga Tõnisson peale sattus, oli Saksa

\footnotetext{
${ }^{58}$ Ferdinand Kull, Esimesi Eesti diplomaate: mälestusi Eesti välisdelegatsiooni tegevusest 1918. aastal (Tallinn: Eesti Päevaleht, Akadeemia, 2010), 171-172; vt ka Kaido Jaanson, "See kummaline eestlane", Looming, 7 (1990), 967.

${ }^{59}$ Laaman, "Välisdelegatsiooni-aeg", 204.

${ }^{60}$ ERA, f. 957, n. 18, s. 28, 1. 20, Tõnisson Ajutisele Valitsusele 18.2.1918.

${ }^{61}$ Nagu kirjutab Gummerus 4. veebruaril, olid Tõnisson ja Kesküla kohtunud päev varem, SRA, Gummeruksen kokoelma 602:220, k. 51, Gummerus Roppile, 4.2.1918.

${ }^{62}$ ERA, f. 957, n. 18, s. 28, 1. 20, Tõnisson Ajutisele Valitsusele 18.2.1918.
} 
mereväestaabi agent Konrad Westlin. Seal viibis Westlin seetõttu, et talle oli antud ülesandeks kindlaks teha, millega Kesküla tegeleb, ning ühtlasi hoida silma peal Tõnissonil, kelle kohta tuli välja uurida, ega ta sakslastega läbi rääkides samas ka Entente'i maadega ühendust ei kavatse võtta. Huvitaval kombel väidab Westlin oma mälestustes, nagu oleks Tõnisson sealsamas kinnitanud kõike, mida Kesküla eestlaste poliitiliste kavatsuste kohta väitis. ${ }^{63}$

Tõnisson kirjutab oma raportis, et saadud halvale muljele vaatamata arvanud ta siiski, et Kesküla kogemused võivad sellegipoolest kasulikuks osutuda. Juba samal õhtul telefoneeriski Kesküla Tõnissonile ning pakkus, et võib teda tutvustada "Prantsuse saatkonnas töötava Dr. W'ga" (André Waltz), uurimaks Prantsuse valitsuse suhtumist Eesti iseseisvuspüüetesse. Tõnisson haaras pakkumisest kohe kinni, mis viis kohtumiseni Prantsuse saadikuga ja hiljem de facto tunnustuse saamiseni. ${ }^{64}$ Seda Tõnisson ilmselt ei teadnud, et Prantsuse saatkonna pressiatašee Waltz oli juba mõnda aega toimetanud informatsioonibülletääni Läänemere regiooni idaosa rahvastest, mille Eestit puudutavad osad kirjutas peamiselt Kesküla. Bülletääni saadeti valitsusasutustele Pariisi, kus seda luges ka Pichon. ${ }^{65}$ Suhted Waltzi ja Kesküla vahel olid seega enam kui lähedased.

Järgmisel päeval helistas Kesküla Tõnissonile taas ning tegi ettepaneku kohtuda, et Eesti büroo ja Maapäeva esindaja vahelised suhted läbi arutada. Kohtumisele saabus Kesküla koos sekretär Oskar Elevandiga. Vestlus algas põhjaliku tutvustusega Eesti büroo kohta, mis olevat asunud tegevusse juba sõja alguses, eesmärgiga Suur-Eesti loomine (Eestimaaga tuli liita ka Liivimaa ja Ingerimaa) ning viimase faktiline iseseisvus Venemaast. Selle sihi saavutamiseks olevat Kesküla nii Keskriikide kui ka Entente'i diplomaatiat ära kasutanud, et saaks võimalikuks Skandinaavia-Balti suurvõimu sünd eesotsas Rootsiga. Venemaal aga pidi toimuma revolutsioon, milleks Kesküla oli seal Lenini ja Trotski jalule aidanud. Tõnisson, kes ei suutnud seda kõike kuulates oma kõrvu uskuda, mõistis oma sõnul, et "siin tegemist on südame tunnistuseta poliitilise hochstapleriga [hooplejaga], kes aastate jooksul kõik suguste rumalate juttudega on inimeste juures, kes Eestist midagi ei tea, võinud "Eestimaa poliitilise esitaja” osa etendada ja "diplomaati" mängida". Tõnisson kahtlustas ka, et Kesküla ei teinud seda "vististi mitte kõik oma raha eest, mis tema suure asja hääks

\footnotetext{
${ }^{63}$ Konrad Westlin, Drömmen om frihet: hågkomster 1914-1918 (Vasa: Scriptum, 1992), 40-41.

${ }^{64}$ ERA, f. 957, n. 18, s. 28, 1. 21, Tõnisson Ajutisele valitsusele 18.2.1918.

${ }^{65}$ Arens, "Aleksander Kesküla", 35.
} 
"suurema laenu" teel sulaks teinud, vaid vististi, nii hästi Kesk-riikide kui ka Entente sala-summade kulul...". ${ }^{66}$

Kui Tõnisson oli omalt poolt tutvustanud olukorda Eestis, esitas Kesküla oma arusaama Eesti büroo ja Tõnissoni tulevasest vahekorrast. Selle järgi pidi viimane edaspidi tegutsema Eesti büroo juhatusel ja "Eesti büroole kui Eesti diplomaatilisele Zentrumile, kes alles Eesti diplomaatia on loonud, kõigist oma plaanidest ja kavatsustest täielikku aru andma". ${ }^{67}$ Tõnisson ettepanekuga mõistagi ei nõustunud ning vastas, et sooviks küll Keskülalt head nõu saada, kuid mitte mingil juhul ei saa ta Kesküla juhatusel tööle hakata - seda enam, et ta ei tea, milliste nõudmistega tema büroo vähimatki volitust omamata juba kuskil esinenud on.

Kesküla omakorda pidas naiivseks arusaama, et Eesti diplomaatiat peaks ajama Eestist saadud volitusega, sest "see oleks ometi lóbus, kui Eestist, kus arusaamine alles 18. aastasaja tasapinnal seisab, tahetaks nõudmisi avaldada, mis Eesti diplomaadil tuleks silmas pidada". ${ }^{68}$ Lisaks leiduvat ametlike esindajate seas kaabakaid nagu Mihkel Martna, kes oli "sihikindlalt kihutustööd seks teinud, et Saksamaa oma väed Eestimaale saadaks". Koostööks seega võimalus puudus ning Eesti büroo ja Maapäeva esindajad lahkusid teineteisest "õige diplomaatilises viisakuses, ühtlasi aga jaheduses". ${ }^{9}$

Tõnissoni ja Kesküla läbirääkimiste ebaõnnestumises mängis ilmselt teatavat rolli varasemate konfliktide järelkaja, nagu ka Tõnissonile halva mulje jätnud suurustamine ja kindlasti ka mõlema mehe kurikuulus domineerimisvajadus. Ent peamine vastuolu oli õiguslik ning tulenes erinevusest paradiplomaat Kesküla ja Maapäeva volitusega protodiplomaat Tõnissoni vahel. Ennast rahva ametlikuks esindajaks pidava Tõnissoni jaoks ei olnud kuidagi vastuvõetav Keskülale alluda, samas kui Keskülale tundus naeruväärne end sel viisil Eesti oludega kammitseda.

Kohtumisel, mis kuskile ei viinud, olid ometi omad tagajärjed. Tundub, et Tõnisson piirdus vähemalt esialgu vaid Kesküla naeruvääristamisega Eestisse saadetud raportis. Kesküla aga alustas Prantsuse saatkonna kaudu Tõnissoni-vastast aktsiooni. Viimase võib-olla varaseim tulemus oli see, et prantslaste positiivne arvamus Tõnissoni kohta, mida Thiébaut veel 5. veebruaril väljendas ${ }^{70}$ oli kaks päeva hilisema kuupäevaga dateeritud

\footnotetext{
${ }^{66}$ ERA, f. 957, n. 18, s. 28, 1. 23, Tõnisson Eesti Ajutisele Valitsusele 18.2.1918.

${ }^{67}$ Ibid., 24.

${ }^{68}$ Ibid.

${ }^{69}$ Ibid., 25-26.

70 Thiébaut Pichonile 5.2.1918, Jaan Tõnisson Eesti välispoliitikas, 60.
} 
pikas, Waltzi koostatud ja Kesküla poolt inspireeritud ülevaates asendunud hoopis teistsuguse perspektiiviga.

Seal väidetakse, et (mh Tõnissoni levitatud) info, nagu oleks Maanõukogu vanematekogu Eesti iseseisvaks kuulutanud, on vale - Maanõukogu olevat avaldanud ainult sellesisulist soovi. Ka Poska ja Seljamaa olid Peterburi Prantsuse saatkonnas palunud mitte Eesti iseseisvuse tunnustamist, vaid kõigest võimalust rahukonverentsist osa võtta. Väärinfo olevat levinud Soome ja Rootsi saksasõbralikus ajakirjanduses, kus avaldatakse üldse igasuguseid ebaõigeid teateid Eesti kohta, eesmärgiks jätta mulje, et kui Saksamaa peaks Eesti okupeerima, siis toimub see elanikkonna soovil kaitseks "Vene anarhia ja Inglise imperialismi” eest. Samu püüdeid esindasid ka enamlaste Stockholmi esindaja Vorovski poole pöördunud baltisaksa saadikud, kes kinnitasid, et Eesti rahvas soovib astuda Saksa protektoraadi alla. See kutsus esile kaks reaktsiooni: esiteks said parunid ajakirjanduses vastulöögi Eesti büroolt "mis tõepoolest esindab rahvast", teiseks esitas Rootsi valitsusele ja kõikidele saatkondadele oma protesti ka “deputaat Tõnisson”, kes oma märgukirjas küll kinnitab, et ainult Maanõukogul on õigus pöörduda abi saamiseks välisriigi poole, kuid ei soovi mingeid vaenulikke aktsioone Saksamaa vastu ja deklareerib, et uus kord kaotab ainult baltisakslaste poliitilised (st mitte majanduslikud) privileegid. Konservatiivne partei, millesse Tõnisson kuulub, seisab seega parunitele ja Saksamaale lähedal, mis ilmnevat sellestki, et Tõnisson kohtub Stockholmis lisaks Entente'i maade esindajatele pidevalt ka vaenlase agentidega. Neist ühele soomlasele Gummerusele oli ta ütelnud, et ka tema eesmärgiks on "iseseisva Eesti loomine Saksa protektoraadi all”. Seega: selle asemel, et toetada Tõnissoni ja tema mõttekaaslaste manööverdavat tegevust, oleks liitlastel õigem toetada hoopis neid eestlasi, "kes otsustavalt võitlevad Saksamaa taotluste vastu”. Lisaks on ilmne, et Maanõukogu, mis pooldas suurmaaomandi säilitamist, ei toetanud ka rahvas - vastasel juhul oleks see oma saadikute kaitseks üles tõusnud. Tõnisson, kes on teele läkitatud ühekorraga nii laiali saadetud kui ka avaliku arvamuse poolt hukka mõistetud Maanõukogu büroo poolt, ei esinda seega tegelikult kedagi ning iseseisvuse ja baltisakslaste küsimuste lahendamine on veebruari lõpus kokku tuleva Asutava Kogu kätes. ${ }^{71}$

\footnotetext{
${ }^{71}$ Jaan Tõnisson Eesti välispoliitikas, 6o-63. Seda, et raporti aluseks oli Keskülalt saadud informatsioon, kinnitab ka Kalervo Hovi: Kalervo Hovi, vt Cordon sanitaire or barriére de l'est: the emergence of the new French Eastern European alliance policy 1917-1919 (Turku: Turun yliopisto, 1975), 114.
} 
Bülletäänis Tõnissonile antud hinnang Prantsuse Stockholmi saatkonnas ja välisministeeriumis kindlasti puhtal kujul kehtima ei jäänud, kuid idanema hakanud kahtlustused osutusid püsivateks. Märtsikuus, pärast teiste delegatsiooniliikmete saabumist, käisid Tõnisson, Piip, Pusta ja Virgo uuesti Thiébaut juures sõidulubasid ja Asutavale Kogule tunnustust taotlemas. Thiébaut teatas sel puhul välisministeeriumile, et Piibu, Pusta ja Virgo vastuvõtmine Prantsusmaal "pakub teatud huvi", juhul kui nende suhtes "pole võetud mingeid eelnevaid kohustusi". Samas kirjutab Thiébaut, et Tõnisson, kelle kahtlustäratavast käitumisest varemgi juttu oli olnud, kohtub ikka veel väga tihti Saksa teenistuses olevate Soome aktivistidega ning välisdelegatsiooni palvet Asutavat Kogu de facto tunnustada ei tohiks seetõttu ilma tingimuste ja garantiideta vastu võtta "ilma et eelnevalt oleks teada, mil määral Eesti Asutav Kogu suudab kaitsta oma iseseisvust Saksamaa suhtes." ${ }^{\prime 2}$ Nagu teada, siis tunnustus tulemata siiski ei jäänud, küll aga võis see nende reservatsioonide tõttu mingil määral hilineda.

Järgmine Keskülaga kohtunud delegatsiooniliige oli teistest kauemaks Helsingisse jäänud Ferdinand Kull, kes alles mai keskpaiku Stockholmi jõudis. ${ }^{73}$ Veendunud, et kolleege seal ei viibi, siirdus mõne päeva pärast Pariisi sõita kavatsev Kull kohe Prantsuse saatkonda. Seal tutvus ta saadik Thiébaut' ja Waltziga, kes, nagu Kull oma mälestustes märgib, olid tänu lähedastele suhetele Keskülaga Eesti oludest õige hästi informeeritud. Kull kuulis ka, et Eesti iseseisvuse de facto tunnustus Prantsusmaalt olevat tulnud nii ruttu just tänu Kesküla eeltööle. Kuna Waltz avaldas lisaks imestust, miks välisdelegatsioon sellist vilunud jõudu ära kasutada ei taha, otsustas Kull vana tuttavaga kokkusaamise korraldada. ${ }^{74}$

Erinevalt Kulli mälestustes kirjutatust, jagati temaga tõenäoliselt juba sellel või mõnel peatselt järgnenud kohtumisel kahtlusi, et Tõnisson ja Martna on saksameelsed. Martnat süüdistas Waltz otsesõnu Saksa agendiks olemises, tuues selle tõendiks Pusta poolt 1917. aasta suvel Tallinna Teatajas avaldatud artikli, millest ta oli kuulnud kahtlemata Keskülalt. Lisaks olevat Martna puhul kahtlane, et ta oli sõitnud Eestisse tagasi Saksamaa kaudu

\footnotetext{
72 Thiébaut Pichonile 19.3.1918, Jaan Tónisson Eesti välispoliitikas, 78-79. Hetkel seletamatu kurioosumina võib mainida Hella Wuolijoki mälestustes leiduvat märkust, et "mõni kuu hiljem, kui Eesti valitsuse delegatsioon Tõnissoni ja professor Piibuga eesotsas oli Stockholmis Prantsuse saadiku jutul Eestimaa iseseisvuse tunnustamise asjus kutsuti sinna juurde tõlgiks ja spetsialistiks K. [Kesküla], kes eriti viisakalt abistas Tõnissoni ja delegatsiooni ning tegutses väga korrektselt, toetades Eestit ümbritsevate riikide saatkondade juures", Hella Wuolijoki, Ülikooliaastad Helsingis 1904-1908 (Tallinn: Eesti Raamat, 1995), 170.

${ }^{73}$ ERA, f. 957, n. 18, s. 31, 1. 94, Kull Pätsile 4.5.1918.

${ }^{74}$ Kull, Esimesi Eesti diplomaate, 161-162.
} 
ning küsimusi tekitavat, milliste rahadega antakse välja ajalehte Sotsiaaldemokraat. Tõnissoni oli Kesküla lasknud paista halvas valguses seeläbi, et jutustas Waltzile vääriti ümber 20. jaanuaril Stockholms-Tidningenis ilmunud intervjuud, millest jäänud mulje, nagu poleks Tõnissonil Saksa okupatsiooni vastu midagi. ${ }^{75}$

Kohtumine Keskülaga, nagu Kull seda oma mälestustes kirjeldab, kujunes sarnaseks Tõnissoni ja Kesküla omale, millest Kull kuulis alles hiljem. Jällegi ilmus Kesküla kohale koos Oskar Elevandiga ning ka Kull sai kuulda, et Kesküla hakkas Eesti iseseisvuse heaks tööle juba maailmasõja algul, selleks eeskätt oma rikka naise raha kasutades. Tema teene olnud Saksa abiga Vene revolutsiooni korraldamine, et murda Venemaa sõjaline ja majanduslik jõud. Tänu sellele tõusid enamlased Venemaal võimule ja sõlmisid Saksamaaga rahu, samas kui Eesti "pääses möllust Saksa sõjaväe politseilise okupatsiooni läbi”. ${ }^{76}$ Sakslased aga, lasknud end naeruväärse Balti hertsogiriigi ideega haneks tõmmata, kindlustasid eestlastele liitlaste sõpruse - kes juhul, kui Venemaal poleks valitsenud enamlus ja Eestis sakslased, poleks Eesti iseseisvusest midagi kuulda tahtnud.

Kesküla oli sakslaste rumaluse ära kasutamiseks asutanud Stockholmis Eesti büroo ja sõlminud head sidemed Prantsuse ja Inglise saatkondadega, neid järjekindlalt Eesti oludest teavitades. Raskem töö oli juba tehtud, kui Tõnisson Stockholmi saabus, kuigi viimane arvanud, et "prantslased ja inglased just tema ilusate silmade pärast Eesti iseseisvuspüüdu nii soojalt toetanud". ${ }^{77}$ Tõnisson ise oli asjale oma amatöörliku käitumisega ennem halba teinud, nagu Kesküla Tõnissoni ja Thiébaut' kohtumise juures tõlgina viibinud Waltzi käest oli kuulnud.

Välisdelegatsiooni ja Eesti büroo koostööküsimust arutades jäi Kullile aga mulje, et Kesküla ihkas kõigele vaatamata siiski välisdelegatsiooniga mingisse ametlikku vahekorda astuda, Kulli arvates selleks, et "Eesti büroo endisele ja tulevasele tegevusele teatud ametlikku pitsatit saada, endiseid võimalikke patte ja üleaisaviskamisi likvideerida ja nüüd juba Eesti ametliku diplomaadina karjääri teha" ${ }^{78}$ Samas muutsid Kesküla kõrkus ja despootlik iseloom talle võimatuks mõtte kellelegi allumisest. Eriti puudutas see Mihkel Martnat, kellel "elus kunagi kõrgemat ideaali pole olnud kui ainult võimalikult rohkem raha kokku ajada ja iriseda kõige suhtes, millest

${ }^{75}$ ERA, f. 957, n. 18, s. 31, 1. 193, Kull Tõnissonile 14.6.1918, ERA.957.18.31, 193; f. 2124, n. 2, s. 321, 1. 155, 157, Martna Kullile, dateerimata, ERA, f. 2124, n. 2, s. 321, 1. 155, 157; f. 2124, n. 2, s. 321, 1. 206-207, Tõnisson Kullile 16.6.1918.

${ }^{76}$ Ibid., 163.

77 Ibid., 164.

${ }^{78}$ Ibid. 
ta aru ei saa”. Sellele vaatamata lepiti kokku, et Kull arutab Eesti büroo ja välisdelegatsiooni koostöövõimalusi teiste delegatsiooniliikmetega ${ }^{79}$

Kuna teadaolevalt on Kull seda kohtumist kirjeldanud ainult oma palju hilisemates mälestustes, on raske ütelda, millised tunded teda Keskülaga kohtudes tegelikult valdasid. Siiski näib, et Kulli suhtumine võimalikku koostöösse Keskülaga oli positiivsem Tõnissoni omast. Esiteks olid Kull ja Kesküla vanad sõbrad, teiseks näib, et Kullile mulje avaldamine õnnestus paremini. Võimalik, et Kullile avaldas juba sellal mõju Thiébaut'lt ja Waltzilt ning Keskülalt kopenhaagenlaste (Tõnisson, Menning ja Martna) saksasõbralikkuse kohta kuuldu. Igatahes jäi koostöövõimalus avatuks.

\section{Protest Saksa okupatsiooni vastu}

23. mail 1918 sõitis jätkuvalt Prantsuse sissesõiduluba ootav Kull Tõnissoni kutsel Kopenhaagenisse nõupidamisele. Seal tõstatati küsimus ka Skandinaavias “Sini-Musta-Valkoineni” taolise brošüüri väljaandmisest ning ilmselt tegi Kull ettepaneku selleks Kesküla kontakte ja raha ära kasutada. ${ }^{80}$

Selleks ajaks juba Kesküla poolt blameeritud Tõnisson ja Martna mõtet muidugi heaks ei kiitnud. Tõnisson rääkis Kullile omaenda kokkupuutest Keskülaga, nagu sellestki, et viimane oli 2. märtsil saatnud Stockholmi ajalehtedele Eesti büroo egiidi all "hochstaplerlise teadaande" justkui oleks Prantsuse valitsus tunnustanud Eesti Asutavat Kogu mitte Tõnissoni, vaid hoopis "Eesti-, Liivi- ja Ingerimaa huvisid kaitsva Eesti välisbüroo" vastava palve peale. ${ }^{81}$ Oma saksasõbralikkuse-kahtluse asjus koostas Tõnisson Prantsuse saadikule kirjaliku seletuse, mille Kull hiljem ära viis.

Ka Martna esitas Waltzile vastuseks kirjaliku selgituse. Selle järgi oli talle 1916. aasta detsembris Zürichis tehtud "kellegi sakslase poolt" ettepanek Saksamaal eesti soost sõjavangide seas mingeid ülesandeid enda peale võtta, sh eestikeelset ajalehte toimetada. 1917. aasta maikuus oli Martna sellest oma avalikus kõnes rääkinud, millest Pusta oli Maapäeva valimiste ajal teinud "inetuma süüdistuse mida ta isegi uskuda ei võinud" ${ }^{82}$ Martna kinnitas, et tal pole Saksa valitsuse vastu mingeid kohustusi ning ta soovib Saksamaale pääseda ainult selleks, et seal Eesti iseseisvuse heaks tööd

\footnotetext{
${ }^{79}$ ERA f. 2124, n. 2, s. 321, 1. 164, Tõnisson Kullile 16.6.1918.

${ }^{80}$ Ibid., $166-172$.

${ }^{81}$ ERA, f. 2124, n. 2, s. 321, 1. 168, 206, Tõnisson Kullile 14.6.1918; Kull, Esimesi Eesti diplomaate, 172. Nagu on märkinud Olavi Arens, siis, ehkki Prantsuse tunnustuse saamise juures oli Keskülal tõesti mõningaid teeneid, saadeti tunnustus ometi Tõnissonile, mitte Keskülale: Arens, "Aleksander Kesküla”, 35.

${ }^{82}$ ERA, f. 2124, n. 2, s. 321, 1. 154-155, Martna Kullile, dateerimata.
} 
teha - oleks ta Saksamaa sõber, oleks tal juba ammu Berliini sõita lubatud, samas kui Kesküla seal juba mitu aastat vabalt käia saab. ${ }^{83}$ Vastusüüdistuseks pani Martna kirja ka muu kompromiteeriva info Kesküla kohta, sh viimase kahtlane jõukus, sagedased välissõidud, Artur Siefeldi ja fiktiivse sotsiaaldemokraatliku seltsi juhtum, ettepanekud Vildele ja Lossmanile jne. Kesküla sidemeid liitlastega seletas Martna Kullile sellega, et Kesküla neile ilmselt "sakslaste konfidentsiaalseid teateid edasi toimetab" ${ }^{84}$

Kuna Keskülal, kes iseenesest võis ju olla Eesti iseseisvuse pooldaja, oli seega "musti jälgi, mida Eesti iseseisvuse asi ei kannata", otsustas ametlik välisdelegatsioon tema tegevuse vastu avalikult välja astuda, et "Eesti iseseisvuse asja mitte mingisuguse kahtluse alla langetada". ${ }^{85}$ Deklaratsioon, millega järgnevalt Stockholmi välissaatkondades ja ajalehtes esineti, teatas, "et A. Kesküla ja tema poolt juhitav Eesti büroo ühegi Eesti ametliku asutuse, ajalehe või poliitilise erakonna esindaja ei ole ja et tal puudub igasugune alus Eesti nimel välja astuda; seda võib ta ainult oma isiklikul arvel ja vastutusel teha". Kullile tehti ülesandeks ühisavaldus Stockholmis teatavaks teha. ${ }^{86}$

Eesti büroosse saatis Kull teate postiga, Prantsuse saadiku juures käis aga isiklikult. Viimane kinnitas, et pole Kesküla kunagi Eesti ametlikuks esindajaks pidanud. Thiébaut' palvel kohtus Kull ka Waltziga, kes võttis info samuti rahulikult vastu ning ütles, et ka tema käib Keskülaga läbi ainult kui eraisikuga ning kavatseb seda tulevikuski teha. Päev hiljem teatas Waltz Kullile aga telefoni teel, et teate kätte saanud Kesküla on väga vihane ja lubab suurema skandaali korraldada, kui see ajalehes avaldatama peaks. Ka Waltz soovitas Kullil teate avaldamata jätta, kui seda veel takistada saab, sest" "K. olla juba nii kui nii valmis avalikust tegevusest tagasiastuma ja puhkusele minema". Kull pidi selles küsimuses teiste delegatsiooniliikmetega läbi rääkima. ${ }^{87}$

Paar päeva hiljem, 2. juunil, kui Kull käis uuesti saatkonnas ära viimas kirja Tõnissoni saksameelsuse asjus, kasutas ta juhust, et küsida, kas Kesküla on Prantsuse agent. Seda saadik eitas - Kesküla polevat oma teadete eest kunagi tasu küsinud ega seda vastu võtnud. Thiébaut eitas sedagi,

\footnotetext{
${ }^{83}$ ERA, f. 2124, n. 2, s. 321, 1. 155-156, Martna Kullile, dateerimata.

${ }^{84}$ Ibid., 158-160; Kull, Esimesi Eesti diplomaate, 172-173.

${ }^{85}$ ERA, f. 2124, n. 2, s. 321, 1. 203, Martna Kullile 14.6.1918.

${ }^{86}$ ERA, f. 2124, n. 2, s. 321, 1. 169, "Déclaration"; Kull, Esimesi Eesti diplomaate, 173.

${ }^{87}$ ERA, f. 2124, n. 2, s. 321, l. 181, 183, Kull Tõnissonile 9.6.1918; f. 957, n. 18, s. 31, 1. 193 , Kull Tõnissonile 10.6.1918. Kull, Esimesi Eesti diplomaate, 176-177.
} 
et Kesküla oleks Saksa agent - asjaolu, et Keskülal oli sakslastega suhted olnud, seda veel ei tõestavat. ${ }^{88}$

Samal päeval käis Kull uuesti vestlemas ka Waltziga, kes tähendas mõnevõrra ootamatult, et Prantsuse valitsusele näib kummaline, et Eesti Ajutine Valitsus pole veel protesteerinud Saksa okupatsiooni vastu Eestis "mille tõttu võõral sarnane mulje võib tekkida, nagu ei oleks E. A. V.-l tõsiselt midagid okupatsioni vastu". ${ }^{89}$ Kull nimetas võimalike põhjustena halba ühendust välismaaga ja kartust okupatsioonivõimude survemeetmete ees, kuid pidi omaette isegi möönma, et välisdelegatsiooni sõnavõtud on olnud liiga saksasõbralikud: neis protesteeriti küll okupatsioonivõimude poliitilise taktika, kuid mitte okupatsiooni enda vastu. Kull, kes sellist protesti ka ise vajalikuks pidas, lubas Waltzile selle asjus teiste delegatsiooniliikmetega läbi rääkida. ${ }^{90}$

9. või 10. juunil saatis Kull Tõnissonile oma protestikava, mida põhjendas sellega, et "[s]enikaua kui meie ise mitte oma erapooletuse rikkumise vastu ei ole protesteerinud, ei ole meil mingit alust, et seda erapooletuse tunnistust teistelt nõuda". Samuti arvas ta, et protest annaks välisdelegatsioonile "kindla pinna edasiseks tegevuseks". Pealegi kartis Kull, et muidu jääb tulemata oodatud sissesõiduluba Prantsusmaale. Protestikava enda järgi pidi välisdelegatsioon kui Maapäeva ja Ajutise Valitsuse esindaja avaldama protesti Saksa okupatsiooni kui ennast iseseisvaks kuulutanud Eesti rahva õiguste rikkumise vastu ning nõudma Brest-Litovski rahulepingu kehtetukstunnistamist Eestisse puutuvas osas. Sarnase kirja saatis Kull ka Martnale, kellele pani eraldi südamele, et nemad kui pahempoolsete erakondade esindajad oleksid eriti valvsad, et välisdelegatsioon sakslastele liialt vastu ei tuleks. ${ }^{91}$

Kull, kellel oli tekkimas arvamus, et teda peetakse Prantsuse saatkonnas otsekui pandiks, et Kopenhaageni delegatsiooniliikmete seas saksasõbralik meeleolu võidule ei pääseks, oli valmis isegi Pariisi sõidust loobuma, eriti "nüüd, kus Kesküla poolt meie vastu mõnda aktsiooni võis oodata." ${ }^{2}$ Selle peale ta ilmselt siiski ei tulnud, et alludes Waltzi protestikava-nõudmisele ta võib-olla juba oligi taolise aktsiooni ohvriks langenud.

${ }^{88}$ ERA, f. 957, n. 18, s. 31, 1. 193, Kull Tõnissonile 2.6.1918; Kull, Esimesi Eesti diplomaate, 176-177; Laaman, "Välisdelegatsiooni-aeg", 204-205.

${ }^{89}$ ERA, f. 2124, n. 2, s. 321, l. 180, Kull Tõnissonile 9.6.1918.

${ }^{90}$ Ibid., l. 183-184, Kull Tõnissonile 9.6.1918; Kull, Esimesi Eesti diplomaate, 177-179.

${ }^{91}$ ERA, f. 2124, n. 2, s. 321, 1. 180, Kull Tõnissonile 9.6.1918; f. 957, n. 18, s. 31, 1. 193, Kull Tõnissonile 10.6.1918; Prantsus- ja eestikeelset protestikava vt ERA, f. 2124, n. 2, s. 321, 1. 167-177; Kull, Esimesi Eesti diplomaate, 179-180.

${ }^{92}$ Kull, Esimesi Eesti diplomaate, 180. 
11. juunil sai Kull esialgse vastuse Martnalt, kes oli protestiga põhimõtteliselt nõus, kuid arvas, et kodumaalt on siiski direktiive vaja, sest "[k]ui lugu nõnda on, et kodused mehed o-ga lepiksid ja meie protesterime, siis saab asjalugu naljakaks". ${ }^{93}$ Tegelikult oli Martna ettevaatlikkuse põhjus ilmselt selles, et ta püüdis koos Menninguga pääseda Berliini BrestLitovski rahulepingu revideerimiskonverentsile ning oli karta, et protest seda takistaks. Martna järgi oligi Menning kopenhaagenlastest ainus, kes protesti esitamisele üldse vastu oli. Igal juhul oli otsustatud kavale teine vorm anda, kuna Tõnissonile ja Menningule näivat, et Kull on väga "prantsuse meeste mõju all"..$^{94}$

Järgmisel päeval saigi Kull Tõnissonilt kava uue variandi, mis oli endisest palju pikem, kuid ei väljendanud selgelt põhimõtet, et Eesti protesteerib okupatsiooni vastu iseseisva riigina, mis ei pea Brest-Litovski rahulepingut enda kohta maksvaks. Pigem oli Tõnissoni kava rõhuasetus sellel, et Saksamaa on rikkunud endale rahulepingus võetud kohustust politseivägede abil Eestis avalikku korda jalule seada ning on selle asemel "hirmsa vägivallavalitsuse käima pannud", mille kohta on toodud pikk nimekiri näiteid. Kesküla asjus kirjutas Tõnisson, et Menning on deklaratsiooni juba laiali saatnud ja see ajalehtedes ilmunud ning välisdelegatsioonil Kesküla "kära karta ei tule". Pettunud Kull kirjutas seepeale Martnale "kui delegatsiooni liikmele, kes oma ilmavaadete poolest minule kõige lähemal seisis", et protest on Eesti iseseisvuse kaitseks vajalik ning selleta võidaks Eestit pidada Saksamaa liitlaseks ja käia temaga rahukonverentsil vastavalt ümber. ${ }^{95}$

Kull kirjutas uuesti ka Tõnissonile. Prantsuse saadik oli ütelnud, et Kulli sissesõiduluba Prantsusmaale ei tule enne, kui protest okupatsiooni vastu on allkirjastatud. Iseäranis tarvilik olevat Tõnissoni allkiri. Samuti oli saadik küsinud Kesküla-vastase deklaratsiooni põhjust, millega seoses Kull oli maininud, et Martnal on Kesküla kohta kompromiteerivat materjali. Seepeale oli Thiébaut Martnat jälle Saksa agendiks nimetanud ning ütelnud, et välisdelegatsiooni asi on vastupidist tõestada. ${ }^{96}$

14. juunil sai Kull uuesti kirja Martnalt, kes arvas, et protest tuleb juba sellepärast hästi läbi kaaluda, et välisdelegatsiooni "diplomaatia ja riigiõiguse tundmine on nõrk" ${ }^{97}$ Üldse arvas Martna, et Kulli kava on liiga lühike ja järsk ning püüab liialt inglastele ja prantslastele meeldida. Martna

\footnotetext{
${ }^{93}$ ERA, f. 2124, n. 2, s. 321, 1. 190, Martna Kullile 11.6.1918.

${ }^{94}$ Ibid., 190-191; Kull, Esimesi Eesti diplomaate, 183.

${ }^{95}$ ERA, f. 2124, n. 2, s. 321, 1. 193-197, Tõnisson Kullile 12.6.1918, 193-197; Kull, Esimesi Eesti diplomaate, 184-185.

${ }^{96}$ ERA, f. 957, n. 18, s. 31, 1. 193, Kull Tõnissonile juuni 1918, ERA.957.18.31, 193.

${ }^{97}$ ERA, f. 2124, n. 2, s. 321, l. 199, Martna Kullile 14.6.1918.
} 
oli haavunud ka Thiébaut' kahtlustuste peale ja arvas, et "hr. saadik seal lihtsalt Alexander Suure intrigide ohver on", mis olevat kahetsusväärne, kuna tegemist on ametliku asjaga. Uus vastus tuli Kullile ka Tõnissonilt, kes teatas, et protestitekst tuleb ümber töötada ning saadikule ei tohi mingeid lubadusi anda. Sellega seoses kutsus Tõnisson Kulli uuesti Kopenhaagenisse, et kava läbi arutada. ${ }^{98}$

19. juunil siirduski Kull Kopenhaagenisse, kus protest 3. juulil lõpuks valmis. ${ }^{99}$ Aluseks võeti siiski Tõnissoni kava, kuid lisamärkusega, "[e]t niihästi Vene sovjettide kui ka Saksa valitsus rahvaste enesemääramise õigust pühalikult maksvaks on tunnistanud, siis ei olnud nad mitte õigustatud Eesti saatust otsustama ilma eesti rahva seaduslikkude esindajate kindla nõusolekuta". ${ }^{100}$ Ühes protestiga otsustati välja and dokumentide kogu, millest kujunes tervelt 24-leheküljeline brošüür ("Dokumente zur Beleuchtung der Gegenwärtigen Lage in Estland”). Samuti võeti vastu otsus Kull Prantsusmaa asemel hoopis Ameerikasse välisesindajaks saata. ${ }^{101}$

3. juulil sõitis Kull koos Tõnissoniga Stockholmi tagasi, et protesti levitada. Menning ja Martna tegid sama Kopenhaagenis. Kardetud mõju suhetele Saksamaaga ei jäänud olemata: Menning viis 5. juulil protesti originaali sealsele Saksa saadikule Brockdorff-Rantzaule ja vihastas selle niivõrd välja, et sõidust Saksamaale ei saanud enam juttugi olla. ${ }^{102}$

Ühtlasi võib ütelda, et 29. mai deklaratsioonist ja sellele järgnenud 3. juuli protestist sai alguse tõsisem lõhe Kulli ja kopenhaagenlaste vahel. Kindlasti mängisid selles protsessis pikemas perspektiivis põhirolli isiklikud ja poliitilised vastuolud, eriti orientatsiooniküsimus (erinevalt teistest oli Kulli meelsus selgelt Entente’i sõbralik) ja Kulli vastumeelsus Tõnissoni domineerimispüüete suhtes. Ent konkreetne algimpulss, Waltzi esitatud protestinõue ise, võis üsna suure tõenäosusega pärineda Keskülalt. Sellele viitab Waltzi käitumine ning eriti ähvardus, mille Kesküla tema kaudu välisdelegatsioonile edastas. Vähemalt Eduard Laaman on hiljem kahtlustanud, et just Kesküla "õhutas [...] Prantsuse Stokholmi saatkonda nõudma välissaatkonna liikmeilt järsemat esinemist, millele F. Kull omapead osalt järele andis" ${ }^{103}$

${ }^{98}$ ERA, f. 2124 , n. 2, s. 321, 1. 199-203, Martna Kullile 14.6.1918; Kull, Esimesi Eesti diplomaate, 185; ERA, f. 2124, n. 2, s. 321, 1. 206, Tõnisson Kullile 14.6.1918.

${ }_{99}$ Protesti teksti vt ERA, f. 2124, n. 2, s. 321, 1. 212-224.

${ }^{100}$ Kull, Esimesi Eesti diplomaate, 187.

${ }^{101}$ Ibid., 187-188. Vt ka Suits, “Tagasivaade Eesti Vabariigi sünniaegadele”, 40.

102 Kull, Esimesi Eesti diplomaate, 187-188.

${ }^{103}$ Laaman, "Välisdelegatsiooni-aeg", 205. Mujal on ta sama väljendanud järgmises sõnastuses: "Stokholmi Prantsuse saatkonna avaldustes F. Kullile, iseäranis neis, mis 
Nagu nähtub juba 1918. aasta 7. veebruariga dateeritud bülletäänist ja nagu märgib ka Prantsuse arhiividokumentidega tutvunud Olavi Arens, püüdis Kesküla Stockholmi Prantsuse saatkonda veenda, et tema isiklikud vaenlased Tõnisson ja Martna ning vähemal määral ka teised välisdelegatsiooni liikmed esindavad Eestis konservatiivset, saksasõbralikku voolu. Saatkonna kaudu mõjutas Kesküla mingil määral ka Prantsuse välisministeeriumi. ${ }^{104}$ Oluline oli seejuures fakt, et tõenäoliselt polnud Waltzi ja Thiébaut' huvi tegelik eesmärk mitte lõplikult Eesti iseseisvust toetada, vaid nad tegid seda taktikalistel eesmärkidel tugevdamaks saksavastast vastupanuliikumist. ${ }^{105}$ See muutis prantslased üsna vastuvõtlikeks kuulujuttudele delegatsiooni saksameelsuse kohta.

Oletades, et Kesküla eesmärk oli kätte maksta ja välisdelegatsiooni destabiliseerida, võib öelda, et see tal õnnestus. Esiteks jäi Kull oma radikaalse protestikavaga üksi, kaotades Martna poolehoiu, millega ta ilmselt oli arvestanud. Teiseks hakkas Kull tasapisi järjest enam ka ise uskuma kahtlustusi kopenhaagenlaste vastu ja nägema endas vastukaalu viimaste saksameelsusele.

\section{Eesti informatsioonibüroo asutamine ja Kopenhaageni nõupidamine}

Levinud väidet, nagu oleks Eesti informatsioonibüroo asutatud "vastukaaluks" Kesküla Eesti büroole ei saa pidada päris õigustatuks. ${ }^{106}$ Ettevõtmise juured ulatuvad tegelikult 1917. aasta detsembrisse, kui Gustav Suits sai samal ajal Tõnissoni ja Piibuga ettepaneku välisesindaja ametisse astuda. Ametlikult Suits pakkumist vastu ei võtnud, kuid avaldas nõusolekut eraviisiliselt "oma poliitilise ja ühiskondliku tõetundmise järele" Eesti iseseisvuse heaks tööd teha, milleks ta sai Jaan Raamotilt teatava rahasumma ning Maapäeva arhivaari fiktiivse ametinimetuse. Seega oli Suits algul midagi Soomes tegutseva Maapäeva agendi taolist. Oma mälestustes kirjutab Suits, et tema kontaktid Helsingis viibivate delegatsiooniliikmetega

Eesti delegatsiooni sisesuhete teritamisele sihitud, võib mõneski aimata Kesküla inspireeringuid.” Laaman, "Meie välispoliitika viperused 1918 a. Märkusi F. Kulli mälestuste juurde".

${ }^{104}$ Arens, "Aleksander Kesküla", 35.

105 Konkreetselt Waltzi ja Thiébaut' kohta vt EAA, f. 5377, n. 1, s. 79, Tiit Aleksejev Kaido Jaansonile, 24.11.2001. Prantsusmaa Venemaa-poliitika kohta 1918. aastal laiemalt vt Hovi, Cordon sanitaire or barriére de l'est.

106 Piip, Tormine aasta, 210; Uustalu, Die Staatsgründung Estlands, 24-25. 
(v.a Piip) oli siiski hõredad ning aeg kulus koos August Niguliga brošüüri "Sini-musta-valkoinen" väljaandmisele. ${ }^{107}$

Millegipärast ei maini Suits oma lähedast koostööd Ferdinand Kulliga nii brošüüri koostamise ${ }^{108}$ kui ka informatsioonibüroo heaks propaganda tegemisel ja muudes ülesannetes (sh etapiühenduse organiseerimine). 29. aprillil 1918 Suitsult Poskale saadetud kirjast näib, et büroo asutamise ettepanek oli tehtud Tõnissoni poolt ning suhteliselt hiljuti. Kirjas avaldab Suits nõusolekut "Eesti vabariigi väljamaa esituses, niikaua kui see tähendab Eesti rahva demokraatliku olemasoluvõitlust Preisi-Balti junkruvõimu, militarismi ja klerikalismi vastu, jõudu mööda oma kirjandusliku elukutse kohaselt kaasa töötada"109 ning palub valitsuselt lähemaid direktiive ja rahasummade eraldamist. Samas tundub, et algselt oli ettepaneku taga siiski Suits ise. Juba nädal varem oli Menning palunud Eduard Schwalbel järele uurida, mida Suits õieti Stockholmis tahab teha - kas omal käel poliitikat ajada või välisdelegatsioonile "millekski sekretäri taoliseks" appi tulla. ${ }^{110}$

4. mail kirjutas büroo asjus Pätsile Kull, kes arvas, et "[p]raegu on aeg, kus terve ilma Eesti propagandaga otse üle peaks külvama" ning "Sinimust-valge" taoline teos tuleks viivitamatult välja anda kõikides riikides ja keeltes. Ka Kull palus Suitsule selleks mingi summa eraldada, sest "teatud vahekord ei luba tal päris ilma rahadeta sinna sõita, et otsekohe Tõnissonist rahalises mõttes ärarippuvaks saada". ${ }^{111}$ Juuni teiseks pooleks oli büroo asutamisotsus tehtud ja tarvilik raha leitud.

Suits, kes esialgu pidi Rootsi sõitma samal ajal Kulliga, pääses üle piiri lõpuks jaanipäeval. Ka tema saabudes ei viibinud Stockholmis ühtegi teist delegatsiooniliiget. 4. juulil sai ta siiski Kulli ja Tõnissoniga kokku ning hakkas tegelema protestikirja levitamisega ja looma sidemeid Rootsi ajakirjandusega ${ }^{112}$ Ilmselt sai Suits sel ajal Tõnissonilt ka konkreetse ülesande Kesküla tegevust jälgida.

107 ERA, f. 957, n. 18, s. 31, 1. 92-93, Suits Poskale 29.4.1918; Suits, “Tagasivaade Eesti Vabariigi sünniaegadele", 37-38.

108 Kull, Esimesi Eesti diplomaate, 156-157.

109 ERA, f. 957, n. 18, s. 31, 1. 93, Suits Poskale 29.4.1918.

110 Ibid., 92-93; 96, Kull Pätsile 4.5.1918; ibid., l. 123, Menning Schwalbele 22.5.1918.

111 Ibid., 94-96, Kull Pätsile 4.5.1918.

112 Kull, Esimesi Eesti diplomaate, 187; ERA, f. 957, n. 18, s. 31, 1. 92, Suits Poskale 29.4.1918; Suits, "Tagasivaade Eesti Vabariigi sünniaegadele”, 39-42; ERA, f. 957, n. 18, s. 31, 1. 194 , Kull Tõnissonile 15.7.1918; Ajalehtes avaldatud protestiteateid: "En estnisk protest mot tyskarnas politik i Östersjöprovinserna", Dagens Nyheter, 11.7.1918; "Une protestation des Estoniens", Le Temps, 12.7.1918; "Den tyska terrorn i Estland", Folkets Dagblad Politiken, 13.7.1918; "Tyska invasionen i Estland”, Afton-Tidningen, 14.6.1918. 
Õhk oligi kahtlustustest tulvil. 23. juulil kirjutas Suits Tõnissonile, et "K-a salasepitsused kõiksugu konksusid ette keerutavad", mistõttu on kahtlane, kas Saksamaa asemel Šveitsi määratud Martna sinna viisat saab. Ka Kull arvas, et tema Ameerika sõiduloa saamine venib just seetõttu, et Ameerika saadikut on mõjutanud Thiébaut, kelle taga seisab Waltz ja Waltzi taga "terve intriige" inspireerija Kesküla. ${ }^{113}$

Ühisele vaenlasele vaatamata süvenesid Kulli ja Tõnissoni vastuolud veelgi. 21. juulil sai Kull kirja, millega teda kutsuti tungivalt veel ühele nõupidamisele Kopenhaagenisse. Samuti andis Tõnisson kirjas teada, et tal tasuks Kulli asemel siiski hoopis endal Ameerika saadikuks hakata. Kull, keda selline meelevaldne käitumine haavas, Kopenhaagenisse sõitmisest esialgu keeldus, küll aga siirdus sinna Suits. Suitsult saadud kirja peale järgnes 3. augustil siiski ka Kull. Koosolekul võeti tema käitumine kohe arutusele ning Kullile tundus, et Tõnisson ja Virgo kavatsesid talle selletõttu laitust avaldada, kuid ei tulnud sellega toime. ${ }^{114}$

Nii selle episoodi tõttu kui ka muudel põhjustel süvendas Kopenhaageni nõupidamine veelgi juunikuistest protestivaidlustest alguse saanud lõhet Saksamaale ja Entente'ile orienteeruvate välissaadikute vahel. Kõikide asjassepuutuvate vaidlusteemade üksikasjalik valgustamine nõuaks siinsest oluliselt pikemat käsitlust, kuid peamiselt tekitasid vastakaid arvamusi orientatsiooni- ja kodukorraküsimus, milles Kull (osalt koos Virgo ja Suitsuga) ja Tõnisson (koos Martna ja Menninguga) olid pidevalt vastaspooltel. Ilmselt aitas vastuolude süvenemisele kaasa asjaolu, et kopenhaagenlastele nii geograafiliselt kui ka poliitiliselt kaugeks jäänud Kull oli saanud väärtusliku liitlase Suitsu näol.

Kopenhaagenis vastuvõetud kodukorraga ei tahtnud lõpuks ikkagi Ameerikasse määratud Kull leppida seetõttu, et see nõudis allumist Skandinaavias (st Kopenhaagenis) paiknevale juhatusele, milles omakorda mängis pearolli Tõnisson. Pikad vaidlused orientatsiooniküsimuse üle põhjustas asjaolu, et Kull, Suits ja Virgo olid veendunud Entente’i võidus,

${ }^{113}$ ERA, f. 957, n. 18, s. 31, 1. 204, Suits Tõnissonile 23.7.1918; ibid., 1. 194-195, Kull Tõnissonile 23.7.1918. Kahtlustused ei olnud alusetud. Ameerika saadik Stockholmis Ira N. Morris, kes esmalt oli Kullile sõiduloa andmise poolt, mõtles ümber, kui oli teinud järelepärimisi ja kuulnud, et Kull olevat saksasõbralik, vt Albert N. Tarulis, AmericanBaltic relations 1918-1922: the struggle over recognition (Washington D. C.: The Catholic University of America, 1965), 86. Ameerika diplomaatilist kirjavahetust Kulli kohta vt U.S. Department of State, Foreign relations of the United States, 1918, Russia, vol. II (Washington D.C.: U. S. Department of State, 1931-1933), 831-833, 836-837.

114 ERA, f. 2124, n. 2, s. 321, 1. 244-245, Tõnisson Kullile 21.7.1918; f. 957, n. 18, s. 31, 1. 194-195, Kull Tõnissonile 23.7.1918; f. 2124, n. 2, s. 321, 1. 268-269, Suits Kullile 28.7.1918; ibid., 1. 273, Kull abikaasale 3.8.1918; Kull, Esimesi Eesti diplomaate, 199-203, 205-208. 
Menning ja Martna aga pigem Saksamaa omas ning Tõnisson kahevahel. Kuna Saksamaa kaotus näis siiski järjest tõenäolisemana, võeti lõpuks vastu Kulli algne protestikava Brest-Litovski lepingu vastu ning tunnistati välisdelegatsiooni üldine orientatsioon Entente'i-sõbralikuks. Virgo tegi samas ettepaneku Entente'i riikides asuvatest eestlastest rahvusväeosade loomiseks, mille suhtes jäädi Suitsu ja Kulli poolehoiule vaatamata esialgu äraootavale seisukohale. Ka riigid jaotati taas ümber ning töötati välja informatsioonibüroo kodukord. Kõik asjassepuutuvad dokumendid dateeriti 16. augustiga. ${ }^{115}$

Kuna Maanõukogult saadud volitustes mingeid alluvusvahekordi kindlaks määratud ei olnud, oli kodukorra näol tegemist delegatsiooni sees toimunud usalduse ja peamiselt kogemuse-vanuse pinnal tehtud otsusega. Asjaolu, et Tõnissoni juhiv roll sai seega mingi õigusliku aluse, tähendas omakorda, et tema n-ö laveeriv ja Eesti neutraalsust rõhutav vaatepunkt sai kindlama eelisseisundi kummalegi sõdivatest pooltest suunatud orientatsioonide ees, seda isegi vaatamata välisdelegatsiooni üldiselt Entente'i-sõbralikuks tunnistamisele. Sellest sai omakorda oluline põhjus välisdelegatsiooni süvenevate sisevastuolude taga, kuna taoline kompromisslahendus ei rahuldanud kokkuvõttes kedagi. Kesküla, keda ilmselt terve delegatsiooni poolt kardeti ja ohtlikuks peeti, muutus asjade sellise käigu tõttu "tondiks", keda hakati omavahelistes vastuoludes ära kasutama. Nagu järgnevast näha, hakkasid nii kopenhaagenlased kui ka stockholmlased kahtlustama edaspidi oma vastaspoolt kui mitte sihipärases, siis vähemalt teadmatus kokkumängus isehakanud ebaesitajaga.

\section{Tassa afäär}

1918. aasta augusti lõpu poole aktiveerus informatsioonibürooga tugevdatud välisdelegatsioon senisest enam ajakirjanduses. Nagu märgib Kull, ilmus protest Brest-Litovski lepingu vastu 25.-28. augustil pea kõigis suuremates Skandinaavia ja liitriikide ajalehtedes. ${ }^{116}$ 26. augustil käisid Virgo

115 ERA, f. 957, n. 18, s. 31, l. 186-192, välisdelegatsiooni koosoleku protokollid 1-22.8.1918; f. 2124, n. 2, s. 321, 1. 273, Kull abikaasale 3.8.1918; Kull, Esimesi Eesti diplomaate, 208-215; Suits, "Tagasivaade Eesti Vabariigi sünniaegadele", 43, 58; 16. augusti protesti teksti vt ERA, f. 957, n. 18, s. 31, 1. 210-211.

116 Ajalehtedes avaldatud proteste: "Ententens landsflyktiga estniska regering betraktar tysk-ryska uppgörelsen som värdelös", Aftonbladet, 24.8.1918; "De rysk-tyska förhandlingarna om Estland", Stockholms Dagblad; "Estländarna protestera mot Tysklands och Rysslands planer", Dagens Nyheter; "Estnisk protest mot Estlands anslutning till Preussen", Stockholms-Tidningen, kõik 25.8.1918; "Estnisk protest mot Tysklands Estlandspolitik", Social-Demokraten, 28.8.1918. 
ja Kull ka Prantsuse saatkonnas protesti ära viimas, saadikule "m.s. ka mõnest siinsest eestlasest" teateid andes ning paludes, et "K-st vähemalt Eesti asjus diskretselt kõrvale hoitaks, sest et see meile väga hädaohtlikuks võib saada". ${ }^{117}$

Kesküla polnud tõepoolest mitte puhkusele läinud. 29. augustil avaldas rida suuremaid Rootsi ajalehti Eesti büroo levitatud uudise, et Soome "valgekaartlik valitsus" oli teinud Eesti ajutise valitsuse seni veel vangistamata või välismaal viibivatele liikmetele ettepaneku Eesti ja Soome vaheliseks uniooniks. Ettepanek olevat eestlaste poolt tagasi lükatud. ${ }^{118}$

Kaks päeva hiljem esines ajalehtedes vastulausega Eduard Virgo, kes väitis, et "Eesti valitsus ei tea sellisest ettepanekust midagi" ning taolist plaani võiks kaaluda alles siis, "kui Eesti võib Soomet pidada vabaks ja iseseisvaks riigiks, mitte aga Saksamaa vasalliks" ${ }^{119}$ Lühike protest avaldati päev hiljem ka Soome Stockholmi saatkonna poolt, mille kohaselt polnud Soome valitsus millegi taolise peale isegi mõtelnud, rääkimata vastava ettepaneku tegemisest. ${ }^{120}$

Virgo dementeeringul olid oma järelkajad Soome ajakirjanduses. Esiteks aeti seal segamini kaks bürood ja kirjutati, et Virgo oli dementeerinud Eesti informatsioonibüroo teate. Teiseks solvuti vihje peale, nagu poleks Soome vaba ja iseseisev riik. Ajaleht Uusi Päivä leidis Virgo esindatava "Eesti valitsuse" kohta, et see on ilmselt kokku klopsitud välismaal asuvatest pagulastest "missuguseid valitsusi harrastab iseäranis Inglismaa". Hufvudstadbladet arvas, et kõige vähem sünnib Eesti valitsusele mitte tunnustada "Soomemaad, mille vaba ja iseseisva riigi seisukord on tunnistatud suurriikide poolt". ${ }^{121}$

Rootsi ajalehtedes jäi Soome reaktsioon tähelepanuta, küll aga võttis seal 1. septembril taas sõna Eesti büroo, mis kirjutas, et Virgo väidet Eesti valitsuse teadmatuse kohta peab mõistma nõnda, et Virgo ise asjast midagi

117 ERA, f. 1621, n. 1, s. 126, 1. 26, Virgo Tõnissonile 27.8.1918; f. 1621, n. 1, s. 123, 1. 8, kirjavahetus Stockholmi Eesti Büroo liikme A. Keskküla ebaseaduslikust tegevusest. 118 "Vill Finland union med Estland", Social-Demokraten; "Finland har föreslagit Estland union?”, Stockholms-Tidningen; “Unionsprojekt mellan Finland-Estland?", Aftonbladet; "Union Finland-Estland?", Svenska Dagbladet; "Planerna på en union mellan Finland och Estland?”, Dagens Nyheter, kõik 29.8.1918.

119 "Projektet till en union mellan Finland och Estland", Dagens Nyheter, 30.8.1918, "Ny estnisk uppgift om finskt förslag", Svenska Dagbladet, 30.8.1918; "Finlande et Estonie", Le Temps, 2.9.1918.

120 "Det påstådda finska unionsförslaget till Estland", Stockholms-Tidningen; "Ingen union Finland-Estland", Svenska Dagbladet, mõlemad 31.8.1918.

121 "Viron hallituksen" kanta Suomeen nähden", Uusi Päivä, 31.8.1918; “Också en dementi”, Hufvudstadsbladet, 31.8.1918; ERA, f. 957, n. 18, s. 31, 1. 204, Suits Tõnissonile, 9.9.1918; Seppo Zetterberg, Suomi ja Viro 1917-1919, 111. 
ei tea. Vastav info oli tulnud viimase ametliku kulleriga Eestist, pärineb endise Maapäeva liikme käest ja on juba kuu aega vana. Sama ettepanek olevat "Soome valitsusest kõrgemate instantside poolt" esitatud arutamiseks ka Eesti büroole, mis selle aga tagasi lükkas ja mille tulemusena rahuläbirääkimised "veidi hiljem ühtäkki Tallinnast Berliini ümber kolisid". Seppo Zetterberg märgib, et "valitsusest kõrgemate instantside" all võis mõista Saksamaad, kuid sõna-sõnalt ka Svinhufvudi, kes oli sel ajal tõepoolest taoliste plaanidega seotud ning konsul Toivo T. Kaila kaudu Poskaga läbirääkimisi pidas. ${ }^{122}$ Virgo ja ülejäänud välisdelegatsioon seda mõistagi ei teadnud.

3. septembril järgnes veel üks dementeering Soome saatkonnalt ${ }^{123}$ ning 5. septembril sõnavõtt Suitsult, kes kirjutas, et Kesküla mainitud "viimane ametlik kuller Eestist" ei saanud kindlasti mitte ametlik kuller olla, kuna sääraseid polevat teele saadetud, kõige vähem veel Kesküla-suguste ebausaldusväärsete eraisikute juurde. Mis puudutab uniooniettepanekut, siis oli taolisi mõtteid arutatud, kuid pole põhjust arvata, et selles osas oleks tehtud ametlik ettepanek. ${ }^{124}$

9. septembril Tõnissonile saadetud kirjas teatas Suits rahulolevalt, et uniooniküsimuses on välisdelegatsiooni seisukoht teatavaks tehtud ja "vale-Aleksander" ümber lükatud ning Rootsi suurima teadeteagentuuri uks Kesküla ees "nüüd küll vist jäädavalt" kinni löödud. Ent Suits pidi tunnistama, et Keskülal oli õnnestunud välisdelegatsiooni mitmeti provotseerida, mis tõi kaasa Virgo ebaõnnestunud vastulause, büroode segiajamise ja "Eesti valitsuse" mahategemise Soomes. Lisaks oli Suitsu soomesõbralik pererahvas talle korteri üles ütelnud, kui Kesküla oma provotseeriva teadaande "valgekaartliku valitsuse" kohta lendu lasi. ${ }^{125}$

Ent juba samal päeval sai Suits Eestist teate, et Stockholmis viibib sinna valitsuse ametlike teadetega läkitatud Rudolf Tassa, keda Suits kohe kahtlustas, et tema ongi Kesküla "ametlik kuller". ${ }^{26}$ Et Tassa asukohta kindlaks teha, läks Kull politseisse, kus selgus, et Tassa peatub Hotell Reginas,

122 "Förslaget om en finsk-estländsk union. En dementi av en dementi", Aftonbladet, 1.9.1918; "Ingen union Finland-Estland", Nya Dagligt Allehanda, 1.9.1918; Seppo Zetterberg, "Die finnisch-estnischen Unionspläne 1917-1919", Jahrbücher für Geschichte Osteuropas, 32 (1984), 526; Zetterberg, Suomi ja Viro 1917-1919, 112-113.

123 "Ingen finsk-estnisk union", Aftonbladet, 3.9.1918.

124 "Det finsk-estniska unionsförslaget. Polemik mellan två estniska byråer", Aftonbladet, 5.9.1918. Kogu poleemika kohta vt Zetterberg, "Die finnisch-estnischen Unionspläne 1917-1919", 526; Zetterberg, Suomi ja Viro, 110-113.

125 ERA, f. 957, n. 18, s. 31, l. 204, Suits Tõnissonile, 9.9.1918; vt ka f. 1621, n. 1, s. 31, l. 3, Kull Virgole 8.9.1918.

126 ERA, f. 957, n. 18, s. 31, 1. 204, Suits Tõnissonile, 9.9.1918. 
Oskar Elevandi kõrvaltoas! Järgmisel hommikul helistas Kull talle sinna õige vara, kuid vaevalt oli tal õnnestunud oma aadress teatada, kui kõne katkes. Siiski ilmus Tassa mõne aja pärast Kulli juurde. Selgus, et ta oli teel Prantsusmaale ning talle olid antud kaasa kirjad Tõnissonile ja Martnale, teadaanded Laamanilt ning ajalehenumbrid kuni ärasõiduni. Ka info, et Ajutine Valitsus oli Soome uniooniettepaneku tagasi lükanud, pärines Tassalt, kes oli seda enne ärasõitu Jaan Raamotilt kuulnud.

Saadud ülesande mittetäitmist seletas Tassa sellega, et ei Tallinnas ega Helsingis osatud talle öelda ühegi delegatsiooniliikme aadressi, kellelt sissesõiduluba nõutada. Kesküla õelt oli Tassa saanud lõpuks Elevandi aadressi, kellele ta oli saatnud telegrammi, kuid sellestki polnud abi. Lõpuks oli Tassa hankinud Rootsi viisa kuidagi omal käel. Kui ta 25. augustil Stockholmi jõudis, läks Tassa kohe Prantsuse saatkonda Kulli ja Suitsu aadresse küsima, kuid sealgi neid ei teatud. Seepeale palus ta kaasasolnud paberid koos endakirjutatud aruandega Kopenhaagenisse Tõnissonile edasi saata.

Kesküla ja Elevandiga olnud Tassa kokkupuuted vähesed: Elevant oli saabumispäeval üldse ära maale sõitnud, kuigi talle oli Tassa tulek teada. Keskülaga, kes Tassaga üldse kohtuda polevat tahtnud, oli ta alles Waltzi juures tuttavaks saanud. ${ }^{127}$ Waltzi abiga oli Tassa seejärel saanud välispassi ja Prantsuse viisa ning lootis juba järgmisel päeval ära sõita. Esmalt kavatses ta käia Piibu ja Pusta juures, siis minna mõneks ajaks Lõuna-Prantsusmaale ning seejärel hakata Eesti iseseisvuse heaks kihutustööd tegema.

Näib, et Kull jäi oma Pariisi pagulaspäevade aegse kamraadi veidravõitu seletusega rahule, eriti kuna Tassa lubas Tõnissonile eraldi seletuskirja kirjutada. Waltzi käitumine tundus Kullile aga “enam kui iseäralik”, kuna tema ja Virgo viimase visiidi ajal polnud Waltz selle kohta midagi maininud, et keegi eestlane delegatsiooniliikmeid taga otsib, samuti oli Waltz sellal juba kindlasti olnud teadlik Eesti-Soome uniooniettepanekust. ${ }^{128}$

Ent järgmisel päeval, kui Kull ja Tassa pidid uuesti kohtuma, tuli välja, et Tassa on juba ära sõitnud. Kullile tundus asi nüüd veelgi kahtlasem ja ta arvas, et ärasõit oli "meelega nii rutuliselt korraldatud, et talle mitte anda võimalust minuga uuesti kokku puutuda”. Kullile tundus tõenäoline seegi,

127 Ometi on teada, et juba 1905. aastal kuulus Tassa samasse Tartu sotsiaaldemokraatlikku ringi, mille liikmeks oli teiste seas ka Oskar Elevant ja liidriks Kesküla, vt Sergei Issakov, "Arhiivileide II: kuidas 1905. a. jälitati Tartu keskkooliõpilaste ringe, F. Tuglast ja A. Tassat”, Keel ja Kirjandus, 6 (1977), 353.

128 ERA, f. 2124, n. 2, s. 321, 1. 299-300, Kull välisdelegatsiooni juhatusele 11.9.1918; f. 1621, n. 1, s. 31, 1. 5, Kull Virgole 11.9.1918; Kull, Esimesi Eesti diplomaate, 217-219; ERA, f. 957, n. 18, s. 31, 1. 204-205, Suits Tõnissonile 11.9.1918. 
et Tassal kaasas olnud materjalid on sattunud Kesküla kätte, kuna Virgolt saadud telegrammi järgi polnud need Kopenhaagenisse jõudnud. ${ }^{129}$

Võimalik, et Kull ja Suits oleksid algusest peale Tassaga teisiti käitunud, kui nad teadnuks, et Briti ajalehes Daily News oli juba 6. septembril ilmunud kuulsa Arthur Ransome'i intervjuu äsja Stockholmi saabunud "noore Eesti rahvuslasega", kes oli ise Ransome'iga ühendust võtnud ning muuhulgas talle kinnitas, et Eesti rahvas on kindlalt vastu unioonile "sakslaste käpa all oleva" Soomega. ${ }^{130}$

Päev pärast Tassa lahkumist oli järg Rootsi ajakirjanduse käes. 12. septembril ilmus Afton-Tidningenis artikkel iroonilise pealkirjaga "Elu Eestis Saksa kaitse all”. Anonüümne eestlane, kelle teadetel lugu põhines, oli okupatsiooni suhtes kriitiliselt meelestatud, kuid õonestas millegipärast ka Maapäeva autoriteeti. Artikli järgi oli Eestis pärast veebruarirevolutsiooni moodustatud üldvalimiste teel "Kerenski-maapäev", mis aga Vene madruste ja sõdurite seas peetud lisavalimiste läbi kaotas iseloomu Eesti rahvaesindusena ning oli töövõimetu, kui enamlased selle 1917. aasta novembris laiali saatsid. Maapäeva valitsus, mis edasi tegutses, korraldas seejärel koos bolševikega Asutava Kogu valimised, viimasel keelati aga kokku tulla, kuna enamlased olid selles vähemusse jäänud. Siis põgenes Maavalitsus Haapsallu ning palus võitluseks bolševismi vastu enam-vähem otsesõnu Saksa sõjavägede sissetoomist. Eestis algas seejärel Saksa hirmuvalitsus ja vangistati hulk juhtivaid isikuid, nende seas vastupanu liider, "sakslaste poolt laiali saadetud Tallinna linnavolikogu esimees" Konstantin Päts. Hetkel osutavat eestlased okupatsioonivõimule passiivset vastupanu, toetuseks asjaolu, et Prantsusmaa ja Suurbritannia olid kokku tulemata jäänud Asutavat Kogu ametlikult tunnustanud. Eriti oluline olevat Prantsusmaa tunnustus, mille saavutamisel mängis tähtsat rolli Stockholmis asuv Eesti büroo. ${ }^{131}$

Suits ja Kull käisid järgmisel päeval toimetuses artikli kohta järele pärimas ning selgus, et intervjueeritav oli olnud Tassa, kellel oli tõlgiks kaasas Kesküla. Valeandmete pärast pahane toimetus nõustus ära trükkima Suitsu vastulause, mis 15 . septembril ilmuski. Õienduses selgitakse, et ehkki enamlased saatsid tõepoolest Maapäeva laiali, ei toimunud see mitte viimase töövõimetuse tõttu. Samuti polnud valitsus kunagi Haapsalusse põgenenud ega Saksa interventsiooni palunud. Ka vangistatud Päts pole

129 Kull, Esimesi Eesti diplomaate, 219; ERA, f. 957, n. 18, s. 31, 1. 204-205, Suits Tõnissonile 11.9.1918; f. 2124, n. 2, s. 321, 1. 302, Virgo Kullile 11.9.1918.

130 "Germany's "New Provinces". Esthonians under the iron heel", Daily News, 6.9.1918. 131 "Livet i Estland under Tysklands beskydd", Afton-Tidningen, 12.9.1918; Kull, Esimesi Eesti diplomaate, 217; Suits, "Tagasivaade Eesti Vabariigi sünniaegadele”, 60. 
mitte Tallinna linnavolikogu, vaid Eesti valitsuse juht. Üldse olevat Saksa okupatsioon Eestis sakslaste vandenõu vili, ehkki Eesti büroole mitte päris tundmata jõud (nende all pidas Suits silmas Kesküla ennast) olid ka Rootsi ajakirjanduses selle ettevalmistamisega tegelenud. ${ }^{132}$

Kull, kellel olid sõbra suhtes kahtlused tekkinud, läkitas Tassale 13. septembril Bergenisse kirja ühes artikli tõlkega ning soovis kirjalikku kinnitust, et Kesküla oli tema jutu moonutatult edasi andnud. ${ }^{133}$ Tassa vastused polnud aga päris rahuldavad. Juba 14. septembriga dateeritud postkaardil ta vabandas, et oli pidanud kiiruga lahkuma ja lubas, et kirjutab seletuskirja Tõnissonile siiski valmis. Kaks päeva hiljem kirjutatud vastuses Kulli kirjale teatas Tassa lühidalt, et intervjuu sisu on talle ootamatu, ning kinnitas ettesöödetud väidet, et valeandmete taga on Kesküla. Järgmisel päeval tuli uus kaart, kus Tassa andis teada, et on haige ja lubas terveks saades "asjad jutti ajada". 18. detsembril saatis Kull telegrammi, milles kategooriliselt nõudis õienduse kirjutamist. Vastust enam ei järgnenud. ${ }^{134}$ Ehkki Kull oli kirjas Virgole lootnud, et "K. sellega veel hiilgavalt sisse kukub, kui Tassa käest Bergenist dementi tuleb", jäid need lootused teostumata. ${ }^{135}$

Omaette probleem oli saatkonda viidud pakkidega. 12. septembril käis Kull neid küsimas, kuid kätte ei saanud, sest need olevat juba pakitud ja pitseeritud. Järgmisel päeval polnud pakid veel kohale jõudnud. 14. septembril tuli viimaks esimene pakk, mis sisaldas ainult ajalehti. Päev hiljem sõitis Tõnisson Stockholmi teise paki jälgi ajama. 19. septembri hommikul sai Virgo ka selle lõpuks kätte. Pakis olid puuduvad materjalid ning Tassa "huvitavalt ja usaldust äratavas toonis kirjutatud" raport. ${ }^{136}$

Üsna tõenäoliselt on nimetatud raportiga identne 2. septembriga Stockholmis dateeritud anonüümne "Ülevaade ja aruanne Eesti küsimuse seisukorra üle väljamaal", mille kohta (pealkirja all "A. Keskküla intriigid") märgib Laaman oma teadaannetes, et selle olid saanud 5. oktoobril "paar Tall. E. tegelast Stockholmist tulnud isiku kaudu". ${ }^{137}$

132 Kull, Esimesi Eesti diplomaate, 219; "Estland under det tyska regementet", AftonTidningen, 15.9.1918; ERA, f. 1621, n. 1, s. 123, 1. 8, kirjavahetus Stockholmi Eesti Büroo liikme A. Keskküla ebaseaduslikust tegevusest.

${ }^{133}$ ERA, f. 2124, n. 2, s. 321, l. 306, Kull Tassale 13.9.1918; Kull, Esimesi Eesti diplomaate, 219. 134 ERA, f. 2124, n. 2, s. 321, 1. 311, Tassa Kullile 14.9.1918; ibid., 1. 312, Tassa Kullile 16.9.1918; Tassa Kullile 17.9.1918; ibid., l. 327, Kull Tassale 18.9.1918; Kull, Esimesi Eesti diplomaate, 220.

135 ERA, f. 1621, n. 1, s. 31, 1. 6, Kull Virgole 13.9.1918.

136 ERA, f. 2124, n. 2, s. 321, l. 301, Kull Tõnissonile 12.9.1918; ibid., 1. 308-310, Virgo Kullile 13.9.1918; ibid., 1. 315, Virgo Kullile 14.9.1918; f. 1621, n. 1, s. 126, 1. 40, Virgo Tõnissonile 18.9.1918; ibid., 1. 44-45; Virgo Tõnissonile 19.9.1918.

137 ERA, f. 1583, n. 1, s. 7, 1. 158, "Kodumaalt saadetud teated". 
Kirjutise sisu on lühidalt järgmine: “[k]odumaalt oma pääle võetud kohustuste läbiviimisel” oli autor kohtunud "ühe liiduriigi saatkonna liikmega", keda Eesti küsimus eriti huvitas ja kes oli palju kaasa aidanud Eesti iseseisvuse tunnustamiseks. Nimetatud tegelane (ilmselgelt Waltz) kuulas huviga külalise seletusi elust Eestis Saksa okupatsiooni all ning informeeris teda omalt poolt Prantsusmaa ja Suurbritannia märtsikuistest tunnustustest Asutavale Kogule. Skandinaavia välisdelegatsioonist rääkis härra "üleüldiselt ironiserides", heites ette, et nad olid kohe sakslaste poole pöördunud ja alles seejärel, kui nendega seal tegemist ei tahetud teha, Entente'i riikidega ühendusse astunud. Piibust ja Pustast oli ta hoopis paremal arvamusel. Ent ka Skandinaavia esinduse kahepaiksusest polnud õnneks midagi, sest tänu Eesti büroole, mis oli juba sõja algusest peale Eesti heaks tegutsenud, olevat "Eesti küsimus Pariisis juba küps olnud". Kuna ametlikud välisesindajad Skandinaavias aga igal võimalusel selgitasid, et "nende tegevuste ja üleastumiste taga terve Eesti rahvas seisab" oli Entente'i maade esindajate seas tekkinud lausa arvamus, et kogu Eesti rahvas on saksasõbralik. ${ }^{138}$

Laamanile tundus selle raporti põhjal, et Tassa "keda siin kord ärapraagiti, aga Tartust siia uuesti kaela soovitati" on nähtavasti päris suli - teda oli otsesõnu Kesküla eest hoiatatud, aga ometi oli ta viimasega ühendusse astunud. Laaman kahtlustas sedagi, et ilmselt oli just Tassa Ransome'ile teateid andnud. ${ }^{139} \mathrm{Ka}$ kopenhaagenlased olid üsna selgelt Tassa vastu meelestatud. Nagu Virgo 13. septembri kirjast Kullile välja tuleb, ei saanud ta ikkagi aru, kuidas Tassa oma "2-nädalist peidusolemist" ning Kesküla ja Elevandiga läbikäimist vabandab. 16., 18. ja 19. septembri kirjades Tõnissonile soovitas Virgo viimasel tingimata Waltziga Tassa asjus kõneleda, "et kuulda, mis mees ütleb". ${ }^{140}$

Kulli kahtlused hajusid ilmselt siis, kui ta hiljem Pariisis Tassaga uuesti kohtus ning kuulis, et tema väljasõidule Bergenist oli suuri takistusi tehtud. Tassa oli seepeale Waltziga ühendust võtnud ning selgus, et Tõnisson oli käinud Tassat Kopenhaageni Inglise saatkonnas Saksa agendiks tembeldamas, mistõttu ta oli inglaste "musta nimekirja" pandud. Pikkade sekelduste järel oli ta 31. oktoobril lópuks siiski laevale saanud. Kulli kirjadele

138 "Ülevaade ja aruanne Eesti küsimuse seisukorra üle väljamaal”, ERA 957, n 31, s. 298, 1. 212-214, "Ülevaade ja aruanne Eesti küsimuse seisukorra üle väljamaal”; ERA, f. 1583, n. 1, s. 7, l. 158-159, "Kodumaalt saadetud teated".

139 ERA, f. 1583, n. 1, s. 7, 1. 159, "Kodumaalt saadetud teated"; ibid., l. 159; f. 1583, n. 1, s. 36, 46, "Kodumaalt saadetud teated".

140 ERA, f. 2124, n. 2, s. 321, 1. 308, Virgo Kullile 13.9.1918; f. 1621, n. 1, s. 126, l. 38, Virgo Tõnissonile 16.9.1918; ibid., 1. 40, Virgo Tõnissonile 18.9.1918; ibid., 1. 44-45, Virgo Tõnissonile 19.9.1918. 
vastamata jätmist põhjendas Tassa arvamusega, et ka Kull kui delegatsiooni liige Tõnissoni tegevusega kursis on. ${ }^{141}$

Tegelikult ei teadnud Kull sellest midagi, mis on ilmselt märk, et ka teda kui Tassa sõpra enam täiesti ei usaldatud. Samas näib, et aktsioon Tassa vastu leidis tõepoolest aset. 27. oktoobril kirjutas Bergenis viibinud Martna oma päevaraamatusse, et oli kuulnud, et Tassa ikka veel sealsamas viisat ootab, kuid "[n]üüd olla ta Pariisist sõiduloa saanud ja sõidame vist ühel laeval. Piinlik!”"142

Kindlasti polnud ka Tassa südametunnistus selles, mis puudutab kontakte Keskülaga, puhas. Tõenäoliselt kohtus ta viimasega veel Bergeniski. 20. septembril Keskülale saadetud kirjas kirjutab Elevant, et Waltz oli lubanud inglastega rääkida, et Tassa liikuma saaks, ning iseloomustab kullerit mitte just positiivselt: "[j]]̈̈nda tema pärast igatpidi ja õieti on ta ometegi niisama nagu teisedki". Lisaks kahtlustas Elevant, et kas Tassa "mitte ise kaabakatele ei kirjutanud või telegrafeerinud ja sel moel oma adressi üles andis" ning arvas, et Keskülal on huvitav temalt järele pärida "kuidas nende asjadega on". ${ }^{143}$

Pihtide vahele jäänud Tassa püüdis oma nime siiski puhtaks pesta. Veel järgmise aasta algul protesteeris ta kirjas Suitsule kahtlustuste vastu, nagu oleks ta "ametlikust missioonist sohitsenud". ${ }^{44}$

\section{Välisdelegatsiooni lagunemine}

Septembris 1918 ilmus välisdelegatsiooni dokumendikogu "Pour l'Estonie indépendante", mille toimetaja oli Virgo ja prantsuse keelde tõlkija Kull. Viimasel olid töö käigus tekkinud erimeelsused Menninguga, kes kirjutas ülevaate Eesti küsimusest ja välisdelegatsiooni tegevusest. Kullile kui veendunud saksavastasele ei meeldinud, et Menning oli käinud välja lubaduse anda vähemusrahvustele kultuurilisi õigusi. Samuti ei saanud Kull nõustuda väitega, nagu jäänuks delegatsiooni tegevuspõhimõtted algusest peale samaks. Viimased otsused Entente'i orientatsiooni omaks võtmisest,

\footnotetext{
141 Kull, Esimesi Eesti diplomaate, 220.

${ }^{142}$ Martna, "Katkendid päevaraamatust. Ilmasõda", 46.

143 Yale University Library. Manuscripts and Archives, Keskula Papers, box No. 4, Elevant Keskülale 20.9.1918. Lisaks jõudsid Tassa teated Kesküla kaudu baltisakslaste Stockholmi büroosse. Pole selge, kas Tassa oli sellest ka ise teadlik, vt Eduard Laaman, "Landesratist Landeswehrini. Balti hertsogiriigi välispoliitika", Sõdur, 45/46 (1931), 1175.

${ }^{144}$ Gustav Suits, "Päevaraamat 1919", Tulimuld, 1 (1977), 4.
} 
rahvusväeosade loomisest ja ühisest võitlusest koos Entente’i maadega sakslaste vastu tähendasid Kulli jaoks selles olulist murrangut. ${ }^{145}$

Juba septembri algusest alates oli Kullil kontakt Ajutise Valitsuse sõjaministri kindral Andres Larkaga, kes septembri keskel sõitis Helsingisse, et koos teise kindrali Aleksander Tõnissoniga töötada välja plaanid Eesti rahvusväeosade loomiseks. Ehkki Larka mälestuste järgi seisnes see tegevus peamiselt kodus istumises ja kirjutamises, külastas ta tegelikult juba paar päeva pärast saabumist Briti konsulit, kellelt palus, et eestlastest sõjaväelastel lubataks koguneda Murmanskis ja formeerida väeosad, mis ühineksid Entente'i interventsioonivägedega. Samasisuline ettepanek oli Seljamaa ja Laidoneri poolt tehtud Peterburi Briti saatkonnale juba juuni alguses ning ka Tallinnas heaks kiidetud. ${ }^{146}$

Samal ajal süvenes veelgi lõhe välisdelegatsiooni sees. 20. septembril allkirjastati Kopenhaagenis "Avalik kiri Saksa asekantsler v. Payerile" - pikk vastulause Friedrich von Payerile, kes oli väitnud, et Venemaa rajariigid olid ise Saksa kaitset ja Saksamaaga ühinemist palunud. Stockholmlaste suhtumist kirjutisse väljendab hästi üks selle säilinud eksemplaridest, mis on varustatud Suitsu ääremärkustega. Väidet, et Saksa okupatsiooniväed olid Eesti väeosad desarmeerinud "vaatamata eelnevale kokkuleppele", kommenteeris Suits, et "[s]ellest võiks järeldada, et Eesti mõõduandvad tegurid sakstega komplotis on olnud ja pärast haledal kombel tõmmata saanud. Niisugust arvamust propageeribki K-küla büroo." Teksti lõppu pidas Suits vajalikuks lisada, et von Payeri sõnad ühes järgnevas kõnes, "et ükski naabririik välja ei kannatavat koketteerimist kord pahemale, kord paremale, kord lääne, kord ida poole" olid nagu "[o]tsekohe [Eesti delegatsiooni] kohta münditud". ${ }^{147}$

Kirjutis saadeti 21. septembril Stockholmi ning Kull ja Suits pidid seda ajakirjanduses levitama hakkama. ${ }^{148}$ Suits aga teatas ülesandest kuuldes, et Kull oma nime selle alla panna ei kavatse ning ka tema ei pea võimalikuks kirja levitamisega tegeleda, kuna "[s]oovituseks sarnane v. Payeri ees

145 ERA, f. 1621, n. 1, s. 31, 1. 7-8, Kull Virgole 16.9.1918; Kull, Esimesi Eesti diplomaate, 223-224.

146 ERA, f. 957, n. 18, s. 31, 1. 217, Kull Larkale 8.9.1918; Andres Larka, "Kaks sõitu", Mälestused iseseisvuse võitluspäevilt, I köide: revolutsioon ja okupatsioon 1917-1918, Eesti Ajakirjanikkude Liidu toimetusel (Tallinn: Rahvaülikool, 1927), 189-19o; ERA, f. 957, n. 18, s. 31, 1. 251-153, Kull välisdelegatsiooni juhatusele 03.10.1918; ibid., 1. 239, Larka Poskale (?) 14.10.1918; vt ka ibid., l. 196, "Kodumaalt saadetud teated" 25.9.1918.

147 ERA, f. 957, n. 18, s. 31, 1. 218-222, "Offener Brief an den Vizekanzler des Deutschen Reiches von Payer".

148 ERA, f. 2124, n. 2, s. 321, 1. 332, Virgo Kullile 21.9.1918. 
keerutamine meile ei Amerikas ega ententemail igatahes ei ole". ${ }^{149}$ Üldse olevat esimesed “ümberkobamise kuud” möödas ning Suitsule näis, et ajal, mil kodumaal valmistutakse okupatsiooni vastu sõjaliselt välja astuma, on "Eesti diplomatiliste vabakunstnike etendus "Omal jalgel” ilma ühegi ühise rahvusvahelise taktikata” väga ebaajakohane. Vastupidi: kui välisdelegatsioon Saksamaad Eesti vabariigi vaenlaseks peab, tuleks Saksamaaga diplomaatilised suhted lõpetada, nagu seda kodumaal juba tehtud oli. ${ }^{150}$

Suits, kellele juhatus seepeale kodukorda meelde tuletas, teatas 27. septembril uuesti, et oli “avalikku kirja” Svenska Telegrambyråle pakkumas käinud, kus seda aga vastu võtta ei tahetud. Suits lisas, et isiklikult pole tal läbikukkumise pärast kahju. ${ }^{151}$

Ilmse vastumeetmena Suitsu allumatusele võeti juhatuse koosolekul 26. septembril vastu otsused, et välisdelegatsiooni kulude vähendamiseks tuleb informatsioonibüroo tegevus peatada ja Suits Helsingisse saata, kus ta tegutseks kodumaalt raha saamise nimel, ega naaseks enne, kui suuremad summad käes. Kullil koos abikaasaga soovitati kokkuhoiu eesmärgil informatsioonibüroo ruumidesse kolida või ära Kopenhaagenisse tulla. ${ }^{152}$

Kull ja Suits otsustasid enamiku juhatuse otsustest täitmata jätta. 29. septembril kirjutatud vastuses teatas Suits, et ei või informatsioonibüroo sulgemisega "praegusel saatuslikult-põneval silmapilgul” kuidagi leppida. Kuna juhatusel büroo ülevalpidamiseks raha pole, kohustub Suits vastavad summad ise leidma (see õigus oli talle informatsioonibüroo kodukorras jäetud) ning kavatseb ka Helsingist tagasi pöörduda juba enne suuremate rahade laekumist. Ka Kullil olevat otstarbekam oma korterisse edasi jääda, kuna Suits ei kavatse Soome jääda kauemaks kui nädalaks või pooleteiseks. ${ }^{153}$ Kull ise vastas, et pole teistest enam kulutanud, mistõttu tema kohta pole ka eraldi otsust tarvis. Samuti teatas ta, et ei kavatse kolida ei Kopenhaagenisse ega informatsioonibüroo ruumidesse ning protesteeris ägedalt büroo sulgemise vastu. See olevat viimane, mille juures hetkel kokku hoida. Et delegatsiooni tegevus viimaste sõjauudistega, meeleoludega kodumaal ja Larka sammudega kooskõlas oleks, tegi Kull omalt poolt juhatusele ettepaneku, et okupatsioonivõimudelt nõutaks kõigi poliitvangide vabastamist, Eesti väeosade taasrelvastamist ja kodumaale lubamist, Saksa vägede Eestist välja viimist ning kahjutasu okupatsiooni läbi teh-

149 ERA, f. 957, n. 18, s. 31, 1. 205, Suits Tõnissonile 23.9.1918.

150 Ibid., l. 207; Suits Tõnissonile 24.9.1918.

${ }^{151}$ Ibid., 1. 205-206, Suits Tõnissonile 27.9.1918; ibid., 1. 207, Suits Tõnissonile 27.9.1918.

152 Ibid., 1. 223, "Eesti Delegatsioni juhatuse koosolek", 26.9.1918; f. 2124, n. 2, s. 321, 1. 346, Tõnisson Suitsule 27.9.1918; Kull, Esimesi Eesti diplomaate, 229.

${ }^{153}$ ERA, f. 957, n. 31, s. 29, 1. 206, Suits Tõnissonile 29.9.1918. 
tud kahjude eest (nende nn. nelja punkti väljatöötamisest oli ka Suits osa võtnud). Kull nõudis ka Berliner Tageblattis 17. septembril ilmunud artikli dementeerimist, milles nõuti Brest-Litovski rahulepingu praktilist teostamist Eestis ning mille autor oli ilmselt Menning. ${ }^{154}$

Vahepeal Stockholmis olnud Jaan Kopvillemi teadete põhjal oli Kull omaalgatuslikult koostanud kirjutise Saksa võimude terrorist Eestis, mida ta hakkas saatkondades ja ajakirjanduses levitama. ${ }^{155} 26$. septembril viis Kull selle ka Vene saadikule Gulkevitšile, kellelt kuulis, et Ufas kokkutulnud Venemaa mitteenamlike valitsuste koalitsioon (Ajutine Ülevenemaaline Direktoorium) võiks Eesti iseseisvuspüüdlustele vastu tulla ning lubada ka rahvusväeosade formeerimist. Neis küsimustes oli Gulkevitš nõus valitsusele järelepärimise edastama. ${ }^{156}$

Järgmisel päeval kutsuti Kull Briti saatkonda, kus Helsingi konsul temalt Larka tegevuse üle aru päris. Kull andis sellest meeleldi teateid ning arvas, et eestlased peaksid saama võimaluse luua Entente'iga liidus olevaid rahvusväeosi lisaks Murmanskile ka ülejäänud mitteenamlikul Venemaal, seda mõistagi Ufa valitsuse loal. Eeltingimusena nõudis Kull, et Ufa valitsus tunnustaks Eesti iseseisvust ja lubaks ametlikult väeosade formeerimist millega ka inglased päri olid. Sel ja järgmisel päeval käis Kull ka Prantsuse ja Itaalia saatkondades, kus tutvustas samuti Larka tegevust ja palus toetust Ufa valitsuse juures. ${ }^{157}$

29. septembril kohtus Suits Waltziga, et küsida laenu büroo tegevuse jätkamiseks. Waltz lubas seda omakorda uurida Pichonilt. Päev hiljem koostas Kull märgukirjad Entente'i maadele, milles küsis toetust Ufa valitsuse juures ka kirjalikult. Seejuures märkis Kull, nagu oleks tal oma sammudeks Larka erivolitus. Ühtlasi teavitas ta oma sammudest ka Larkat ning palus neile tema toetust. ${ }^{158}$ Samal päeval saatis Kull Prantsuse saatkonna kaudu Piibule Briti valitsusele mõeldud noodi ühes kirjaga Larka plaanide kohta, milles ta end jällegi erivolituse omanikuna üles andis. Piip vastas

154 ERA, f. 957, n. 18, s. 31, 1. 227-228, Kull välisdelegatsiooni juhatusele; Kull, Esimesi Eesti diplomaate, 230-231.

155 ERA, f. 2124, n. 2, s. 321, 1.341-344, "Estonia sous la terreur allemande"; Kull, Esimesi Eesti diplomaate, 226-227.

156 ERA, f. 2124, n. 2, s. 321, 1. 348, Kulli märkmed 26.9.1918; Kull, Esimesi Eesti diplomaate, $227-228$.

157 ERA, f. 2124, n. 2, s. 321, 1. 347, Kulli märkmed 27.9.1918; f. 957, n. 18, s. 31, 1. 251-252, Kull välisdelegatsiooni juhatusele 3.10.1918; Kull, Esimesi Eesti diplomaate, 228-229.

158 ERA, f. 2124, n. 2, s. 321, l. 347, Kulli märkmed 29.9.1918; f. 957, n. 18, s. 31, 1. 224-225, "An Gouvernement Royal de l'Italie/de la Republique Francaise/du Ruyaume Uni de la Grande Bretagne"; f. 2124, n. 2, s. 321, 1. 351, Kull Larkale 30.9.1918; Kull, Esimesi Eesti diplomaate, 231-233. 
Kullile 1. oktoobril, et on kirja kätte saanud ja koopia Tõnissonile edastanud. Ühtlasi tuligi Kopenhaagenist telegramm, milles Tõnisson nõudis, et Kull oma sammudest üksikasjalikult aru annaks. ${ }^{159}$

Ent samal päeval olid Suits ja Kull kutsutud Waltzi juurde arutama laenu, mida Pusta oli Prantsuse valitsuselt palunud. Waltz ütles, et oli Pichonilt saanud küsimuse, mis seltskond see Rheinselskabet [välisdelegatsiooni varjunimi] õieti on ja kas oleks võimalik taotlusele jaatavalt vastata. Samuti olevat Pichon tundnud huvi "avaliku kirja” vastu. Et laenuvõimalust mitte ohtu seada, teatasid Kull ja Suits, et "olgugi, et kirjas midagi võõriti ei olnud esitatud, meie kirja adresserimist ja selle natukene retuscheritud tooni ebakohaseks oleme märkinud omalt poolt ja selle järele ka talitanud". Samas näitasid nad Waltzile Kulli märgukirja ja nelja punkti, mis pälvisid tema täieliku heakskiidu. Waltz küsis, kas samal seisukohal on ka delegatsiooni teised liikmed ja valitsus. Kui Kull oli seda "umbkaudu" kinnitanud, teatas Waltz, et sellel juhul toetab ta laenutaotlust täielikult. Samuti pidas ta võimalikuks informatsioonibüroole väiksemat laenu anda - juhul, kui viimane edaspidi Prantsuse saatkonna juhtnööre järgib. Suits lükkas selle ettepaneku tagasi, kuid väljendas kirjas Tõnissonile rõõmu, et hea vahekord Waltziga on taastatud ning et bürood vaatamata juhatuse otsusele ei suletud, kuna "on loota, et juhatuse poolt esitatud motivid tähendatud sammude astumiseks kõige lähemal ajal on kõrvaldatud". Kull aga arvas, et ilma tema "Larka algatusel" ettevõetud sammudeta oleks Pusta esitatud soov kohe tagasi lükatud, nüüd aga olevat selle täitumine praktiliselt garanteeritud. ${ }^{160}$

2. oktoobril viis Kull Ufa valitsusele mõeldud märgukirja ${ }^{161}$ Gulkevitšile ning kirjutas päev hiljem lõpuks ka juhatusele aruande. Viimases rõhutas ta, et tema sammud on Larka tegevuse loogiline jätk ning mõeldud selleks, et kõigutada Entente'i riikides levinud arvamust, et Eesti peab jääma föderatiivse Venemaa osaks. Kuna Vene enamluse lõpp on ukse ees, olevat praegu viimane aeg, kui Entente on valmis Eesti iseseisvuspüüdlusi venelaste juures toetama. Et küsimust oli juba välisdelegatsiooni koosolekul

\footnotetext{
159 ERA, f. 2124, n. 2, s. 321, 1. 359-36o, Kull Piibule 30.9.1918; ibid., 1. 362, Piip Kullile 1.10.1918; ibid., 1. 361 Tõnisson Kullile 1.10.1918.

160 ERA, f. 2124, n. 2, s. 321, l. 347, Kulli märkmed 1.10.1918; f. 957, n. 31, s. 29, 1. 207-208, Suits Tõnissonile 2.10.1918, n. 18, s. 31, 1. 252, Kull välisdelegatsiooni juhatusele 3.10.1918; Kull, Esimesi Eesti diplomaate, 231-232.

161 ERA, f. 957, n. 18, s. 31, 1. 235-236, “Au Gouvernement Reuni d'Ufa de la Russie nonbolcheviste". Kulli kirjutis lükati siiski tagasi, kuna Ajutise valitsuse poolt volitamata esindajad Linde ja Kaelas olid resolutsiooni Venemaa föderaliseerumise kohta juba allkirjastanud, vt ERA, f. 2124, n. 2, s. 321, 1. 369, Kull Pustale 8.10.1918.
} 
arutatud ning otsus ainult autoriteetse arvamuse puudumise taha jäänud, kuid nüüd juba tänu Larkale piisavalt autoriseeritud, avaldas Kull lootust, et juhatus tema sammud heaks kiidab, ehkki neist polnud "rutulise ja kindla ühenduse" puudumise tõttu võimalik juhatust varem teavitada. ${ }^{162}$

Ka juhatus oli tegutsema hakanud. 3. oktoobriks oli Suits Helsingis saanud uue manitsuse, kus nimetati otsust informatsioonibüroo sulgeda otsesõnu Suitsu “tegevuse tarvilikuks hindamiseks". Solvunud Suits kirjutas vastu, et vaidlusaluses küsimuses ei lähe juhatuse seisukohast lahku mitte ainult tema, Suitsu, vaid ka Kulli, Larka ja "kogu Eesti rahva aktivsema osa" seisukoht. Samuti tuletas Suits meelde, et talle oli Tõnissoni ja Piibu kõrval esimesena välisesindaja kohta pakutud, ning ähvardas, et kui juhatuse tegevus samas stiilis jätkub, esitab ta selle omakorda "hindamiseks" välisministrile. ${ }^{163}$

Otsustavamalt astus juhatus välja 5. oktoobril, ilmselt pärast Kulli ja Suitsu kirjutiste kättesaamist. Esiteks saadeti Saksamaa kaudu Eestisse telegramm, millega kästi raha ja dokumentide saatmine Suitsu kaudu "lähemate juhtnööride" saabumiseni katkestada. Teiseks koostati Entente’i saatkondadele Stockholmis märgukirjad, milles teatati, et Tõnisson on Ajutise Valitsuse ainus volitatud esindaja Skandinaavias (implitseerides, et Kull seda pole). Kull ise sai kirja, milles teda süüdistati volitust omamata tegutsemises, välisriikide diplomaatide ees kolleegide diskrediteerimises ja pikantse detailina ka selles, et ta olevat omastanud Tõnissonile saadetud Larka kirja. Kõige selle läbi olevat Kull delegatsiooni tööd järjekindlalt rikkunud ning juhatus nõudis, et ta end viivitamata parandaks, ähvardades vastasel juhul meetmeid tarvitusele võtta. Teises kirjas teavitati Kulli otsusest tema Ameerika saadiku volitused tühistada ja volikiri tagasi nõuda. ${ }^{164}$

Need kirjad tõid Kullile 9. oktoobril ära Tõnisson ja Virgo, kes Kulli protesti järel tõmbasid kirja omistamist puudutava etteheite siiski maha. 11. oktoobril kirjutas Kull pika vastulause, milles oletas, et ainus viis, kuidas ta sai olla välisesituse tööd "järjekindlalt rikkunud”, oli protestiettepanekuga juuni algul, põhjendatud loobumisega ettepanekust korterit vahetada ja üldse oma tegevusega "mille basiseks entente riikide lõpulik võit ja eesmärgiks entente sõbralikkus, kui Eesti iseseisvuse püüete tähtsam faktor”.

\footnotetext{
162 ERA, f. 2124, n. 2, s. 321, 1. 348, Kulli märkmed 2.10.1918; f. 957, n. 18, s. 31, 1. 251-253, Kull välisdelegatsiooni juhatusele 3.10.1918.

${ }^{163}$ ERA, f. 957, n. 31, s. 29, 1. 208, Suits Tõnissonile 3.10.1918.

164 ERA, f. 957, n. 18, s. 31, 1. 295, välisdelegatsioon Ajutisele valitsusele 05.10.1918; ibid., 1. 237, Tõnisson, Menning, Martna ja Virgo Itaalia saadikule 5.10.1918, 237; ibid., 1. 272, välisdelegatsiooni juhatus Kullile 5.10.1918; ibid., 1. 260, välisdelegatsiooni juhatus Kullile 5.10.1918.
} 
Vastukaaluks tuletas Kull meelde suviseid kahtlustusi Martna ja Tõnissoni vastu, põhjuseks Pusta artikkel ja läbikäimine Saksa saatkonnaga, ning süüdistas juhatust, et see oli ka hiljem ja tema selja taga saksasõbralikku tegevust jätkanud. Seetõttu teatas Kull, et ei pea võimalikuks Tõnissoni, Martna ja Menningu juhatusse edasijäämist ning tegi ettepaneku määrata sinna delegatsiooni Entente'i maades viibivad liikmed. Lisaks pani Kull "praktiliste sammudena" ette kohe alustada sõjaväeosade formeerimist, nõuda sõjavangide vabastamist ja okupatsiooni eest kahjutasu ning algatada baltisaksa aadli väljasaatmine Eesti Vabariigi piirest "edaspidiste äraandmiste ja intriigide" ära hoidmiseks. Mis puudutas Entente'i maadele antud märgukirja, küsis Kull näha Tõnissoni volitust, et veenduda, kas ta selles üldse on Ajutise Valitsuse esindajaks määratud. ${ }^{165}$

Samal ajal oli Suits pidanud Helsingis läbirääkimisi Larkaga, kelle kohta ta 8. oktoobril Kullile teatas, et "Bergström on õige sümpaatlik, aga ühtlasi ettevaatlik ja kinnine mees". Larka polnud kõssanudki Suitsu ettepaneku peale Kullile tagantjärele volitust saata, ehkki ta oli viimase sammud heaks kiitnud. 11. oktoobril teatas Larka ka Tõnissonile, et "Kotkas" pole erivolitusi saanud. Samas arvas Larka oma kirjas Poskale, et segadus ei toonud asjale siiski kahju, kuna "oli ju tarvis liitlastele teada anda, et meie nende poole hoiame, milles nemad nähtavaste kahtlesid". 166

Tõnisson oli avaldanud soovi, et Larka Skandinaaviasse sõidaks, millega viimane oli ka päri. 15. oktoobril hankis Kull Rootsi sissesõiduloa. Ado Luha varjunime all ette võetud reisi on Larka üldjoontes ise kirjeldanud, libisedes seejuures küll mööda kõigest välisdelegatsiooni sisekonfliktiga seostuvast. ${ }^{167}$ Ometi mängis ta selle lõpustaadiumis olulist rolli.

Schwalbe oli Kulli juba 21. septembril informeerinud, et välisdelegatsiooni juhatus kavatseb temast vabaneda. 19. oktoobril kirjutas Suits Kullile 5. oktoobril saadetud telegrammist raha ja dokumentide asjus, mille kohta valitsus oli Suitsult aru pärinud. Suits kirjutas, et "sarnast sigadust nagu eelpool nimetatud telegramm - vaenulise maa kaudu - ei oleks ma ka meie "Rheinselskabetist" mitte uskunud!" Ka Kull ei jätnud omalt poolt asja teravamaks ajamata, nõudes järgmisel päeval kirjutatud kirjas juhatuselt vastuseid, kas peab paika, et Kopvillemil oli soovitatud temaga Stockholmis

${ }_{165}$ ERA, f. 957, n. 18, s. 31, 1. 244-248, Kull välisdelisdelegatsiooni liikmetele 11.10.1918.

166 ERA, f. 2124, n. 2, s. 321, 1. 400, Suits Kullile 8.10.1918; f. 957, n. 18, s. 31, 1. 196, Larka Tõnissonile 11.10.1918; ibid., l. 239, Larka Poskale 14.10.1918.

167 ERA, f. 2124, n. 2, s. 321, 1. 404-405, Schwalbe Kullile 14.10.1918; ibid., 1. 405, Kulli taotlus Rootsi välisministeeriumile 15.10.1918; ibid., l. 408, Kull Schwalbele 15.10.1918; Larka, "Kaks sõitu", 189-192. 
mitte kohtuda ning kas on tõsi, et Saksa valitsus on välisdelegatsioonile esitanud ettepaneku Berliini sõita ja mida selle peale oli vastatud. ${ }^{168}$

Lõpuni viis juhatus asja 22. oktoobril Larka osavõtul toimunud koosolekul. Protokollis heidetakse Kullile ette, et ta oli volitust omamata ja juhatust informeerimata Entente'i riikide saatkondade juures tähtsaid samme astunud. Oma väidetavat erivolitust polnud Kull ette näidanud, küll aga sai juhatus teada, et ta oli seda Suitsu kaudu Larkalt tagantjärele nõutada püüdnud. Virgole ja Tõnissonile oli Kull ütelnud, et polnud juhatust teavitanud seetõttu, et ta juba ette teadnud, et see tema sammudega ei nõustu. Seetõttu võeti vastu otsus, et Kulli tegevust ja abinõusid, mis "otse kriminalsusesse ulatavad" tuleb pidada kahjulikuks ning valitsusele peab tegema ettepaneku tema volituste tühistamiseks. Suitsu asjas otsustas juhatus, et informatsioonibüroo viljakus ei vasta sellele kulutatud summadele ning "büroo iseloomus põhjenev haavav ja sõbralikku vahekorda järjest rikkuv viis bürood mitte kui abijõudu, vaid kui pommi jalas on tunda lasknud". Eriti selle rolli valguses, mida Suits oli mänginud Larkalt volitust küsides, otsustati teadetebüroo tegevus lõpetada, lisaklausliga, et kui see ka taastataks, ei või büroo juhatamist mingil juhul Suitsule usaldada. ${ }^{169}$

Oktoobri keskel oli Pusta teinud ettepaneku välisdelegatsiooni üldkoosolekuks Londonis, et tekkinud konflikti arutada. ${ }^{170}$ Näib, et pärast 22. oktoobri otsuseid polnud see võimalus enam aktuaalne. Selle asemel kirjutas Kull valitsusele vihase süüdistuskirja juhatuse vastu, milles kurtis, et tema sammude tühjakstunnistamine juhatuse poolt oli viinud olukorrani, et Entente'i riikide vastuseid 30. septembri memorandumitele pole enam üldse oodata. Sellepärast arvas Kull, et Tõnissoni ja Menningu juhatusse edasijäämine (Martna pidi lahkuma Šveitsi) "kõiki meie edaspidiseid püüdeid paraliseerida ähvardab, nimelt, pr. valitsuse juures, kellel, siinse esitaja arvamise järele, nimetatud isikute vastu nende endise taktika järeldusel täielik usaldus puudub". ${ }^{171}$

Ajutine valitsus, millel niigi käed tööd täis, püüdis omalt poolt konflikti vaigistada. 23. oktoobril teatati delegatsiooni juhatusele, et ehkki vormiliselt ei peaks "läbirääkimata eraldisammusid" ette võtma, leiab Kulli tegevus siiski sisuliselt heakskiitmist. Oktoobri lõpupäevadel Helsingisse sõitnud Kull määrati esialgu välisministri ja valitsuse asjaajajaks. Küsimuse lõplik lahendamine pidi jääma välismaale sõitvate valitsusliikmete

168 ERA, f. 2124, n. 2, s. 321, 1. 331, Schwalbe Kullile 21.9.1918; ibid., 1. 412, Suits Kullile 19.10.1918; ibid., l. 413, Kull Tõnissonile, 20.10.1918.

169 ERA, f. 2124, s. 2, n. 321, 1. 417-420, välisdelegatsiooni juhatuse koosolek 22.10.1918.

170 Ibid., l. 403, Virgo Kullile, 14.10.1918; ibid., l. 407, Piip ja Pusta Kullile 15.10.1918.

171 ERA, f. 957, n. 18, s. 31, 1. 277-278, Kull Eesti Ajutisele Valitsusele 24.10.1918. 
hooleks. Novembris andiski välisministri kohusetäitja Otto Strandman korralduse informatsioonibüroo taasavada. ${ }^{172}$

Suits, kes seetõttu Stockholmi tagasi pöördus, märgib oma mälestustes, et novembri lõpupäevil astus tema juurde sisse Briti saatkonna sõjaväeatašee, kes pikema sissejuhatuseta küsis, mida Suits teab Aleksander Keskülast. Juba nädala pärast olnudki Kesküla Rootsist välja saadetud. ${ }^{173}$ Tegelikkus pidi aga olema keerulisem, kuna Kesküla oli Rootsist lahkunud juba septembris. ${ }^{174}$

Millest Suits ei räägi, on välisdelegatsiooni teistkordne aktsioon Kesküla vastu. Nagu ülal mainitud, käis Virgo juba augustis koos Kulliga Waltzi Kesküla eest hoiatamas. 17. septembril viis ta Kopenhaageni Briti saatkonda kokkuvõtte välisdelegatsiooni kompromiteerivatest andmetest Kesküla kohta, millest saatkonnasekretär Watson saatis edasi koopia Stockholmi Prantsuse saatkonda. Tõenäoliselt oktoobris või novembris koostas Virgo sarnase eestikeelse kogumiku ka Ajutise Valitsuse tarbeks. Novembris mainiti "õnneotsijat suguvenda" ajalehtedes ilmselt Laamani kirjutatud artiklis, kus teda süüdistati, et ta "nii sakslastelt kui la liitlastelt raha välja pigistada mõistab" ja hoolega "Eesti saatkonna vastu urgitseb", seda liitlaste ees saksasõbralikkuses kahtlustades. ${ }^{175}$

Hetkel on raske ütelda, mil määral võis välisdelegatsiooni oktoobrikuise lõhenemise taganttõukajaks olla Kesküla, kes "kaabakatele" nende septembris astutud järjekordsete sammude eest kätte maksis. Tundub aga, et vähemalt Waltzi provokatiivne käitumine 1. oktoobri kohtumisel Suitsu ja Kulliga võis olla mõjutatud Keskülast, kes Waltziga vähemalt Elevandi kaudu kindlasti kontaktis oli. Tõenäoliselt on märkimisväärne seegi, et Kesküla oli Rootsist lahkunud Pariisi eesmärgiga - täpselt nagu Kull tegutseda Siberis Eesti rahvusväeosade loomise nimel. Keskülal oli aga raskusi läbisõiduviisa saamisega, kuna inglased olid hakanud teda kahtlaseks isikuks pidama. Pole võimatu, et need probleemid olid seotud Virgo sammude ja hiljem Suitsu juures teostatud järelepärimisega, st Tassa afääri lõpuosa kordus ühtlasi Kesküla endaga. ${ }^{176}$

\footnotetext{
${ }_{172}$ ERA, f. 2124, n. 2, s. 321, 1. 424, Ajutine valitsus välisdelegatsioonile 23.10.1918; f. 1583, n. 1, s. 36, 1. 68, "Kodumaalt saadetud teated"; f. 957, n. 18, s. 31, 1. 281, "Sampo juhtnöörid välistele esitustele", oktoobri lõpp; Medijainen, Saadiku saatus, 56-57.

173 Suits, "Tagasivaade Eesti Vabariigi sünniaegadele”, 63.

174 Kaido Jaanson, "Aleksander Kesküla and Sweden”, Scandia, 69:2 (2003), 166.

175 Vt ERA, f. 1621, n. 1, s. 123, "Kirjavahetus Stockholmi Eesti Büroo liikme A. Keskküla ebaseaduslikust tegevusest"; f. 1583, n. 1, s. 7, 1. 176, "Eesti välisesituse tegevus", ERA, f. 1583, n. 1, s. 7, 1. 176; Sotsialdemokrat, 13.11.1918; Sakala, 19.11.1918.

${ }^{176}$ Kesküla läbisõiduraskuste kohta vt Arens, "Aleksander Kesküla", 35.
} 


\section{Järelkajad Pariisis ja Bernis}

Kui mitte Rootsis, siis vähemalt Prantsusmaal ja Šveitsis jõudis Kesküla välisdelegatsioonile edaspidigi probleeme tekitada. 20. novembril Prantsuse parlamendi välisasjade komisjoni juhi Franklin-Bouilloniga kohtudes pidi Pusta vastama küsimusele, kas Skandinaavia delegatsioon - Stockholmist tulnud teadete põhjal - mitte saksasõbralik ei ole. Pusta ütles, et info on väär ning selgitas Waltzi ja Kesküla suhteid. ${ }^{177}$ Novembri lõpus kõneles Franklin-Bouilloniga Virgo, kes pidi seekord andma seletusi iseenda kohta. Prantslane, kes oli hiljuti ka Keskülaga kohtunud, oli nimelt Waltzilt kuulnud, et Virgo oli Kopenhaagenis "saksasõbraliste ringkondadega" ühenduses seisnud. Virgo omakorda rääkis sama Kesküla kohta ja lubas jätta tema kohta ka kirjalikke teateid. Lisaks pidas Virgo intsidendist kirjutades tõenäoliseks, et tema ja võib-olla ka teiste kahtlustamises "mitte üksnes Herra K-la tegev pole olnud, vaid ka teine hr. K”. Ka Pusta mainib ühes palju hilisemas artiklis, et kuulujutud "mõnede delegatsiooni liikmete saksasõbralikkusest" tulenesid "ühe prantsuse informatsiooni-ametniku R. W. ettekannetest ja põhjenesid öeldavasti ühe meie delegatsioonile lähedal-seisva isiku andmeil". Ilmselt ei pidanud ka tema silmas mitte Kesküla, vaid Kulli..$^{178}$

1919. aasta jaanuaris Londonisse jõudnud Tõnisson oli visadest kahtlustustest vägagi häiritud. Kirjas abikaasale kurdab ta, et riigimehelikkust leiduvat delegatsiooni liikmete seas vähe ning eriti" "A. Piip oma talupojalikus auahnuses väikseid intrige-võtteid tarvitab, et aga oma pisikest "ise" igal pool ette toppida ja laiutada". Piip ja Pusta olid isegi sellega hakkama saanud, et võtsid vastu otsuse Tõnissoni juhatusel mitte tööle hakata, "sest Stockholmist A. Waltzi (i. e. A. Kesküla, F. Kulli + ja G. Suitsi) poolt olevat teated Parisi tulnud, mis Prantsuse valitsuse ringkondades (?!) arvamise olevat sünnitanud, et J. Tõnisson - saksasõbralikku politikat ajanud, kui tema Skandinaavias esitajaks olnud". ${ }^{179}$

Sama murega pöördus Tõnisson Pusta poole, kellelt ta sai 6. jaanuaril pika ja emotsionaalse vastuse. Pusta heitis Tõnissonile ette, et viimane oma kolleegide tööd ja tegevust liiga madalalt hindab, mis eriti hästi ilmnenud tema suvistes ringkirjades ja "isalikes" nõuannetes, mida Piip ja Pusta väga ebakohaseks pidasid. Pusta ja eriti Piip olid Eesti heaks teinud "vististe

\footnotetext{
177 ERA, f. 1624, n. 1, s. 19, 1. 37, Pusta Poskale 29.11.1918.

178 ERA, f. 1621, n. 1, s. 119, l. 2, Virgo Piibule, Pustale ja Martnale 1.12.1918; K.-R. Pusta, "Jaan Tõnisson välispoliitiku ja diplomaadina”, Jaan Tõnisson: koguteos tema üheksakümnenda sünnipäeva tähistamiseks, toim Evald Blumfeldt (Stockholm: Vaba Eesti, 1960), 241. ${ }^{179}$ ERA, f. 1627, n. 1, s. 21, 1. 92-93, Tõnisson abikaasale 3.1.1919.
} 
mitte vähem kui Skandinavia delegatsion" ning ootasid teistsugust suhtumist. Samuti kinnitas Pusta taas, et "meile Inglis- ja Prantsuse valitsuste ja isegi sotsialisti Albert Thomase silmis mitte kasulik ei oleks olnud, kui Piip ehk mina oleksime pidanud teatama, et nüüdsest peale Teie juhatuse all töötame" eriti arvestades kuuldusi Tõnissoni saksasõbralikkusest, mille vastu oli Pusta pidanud nii palju võitlema, et "paljud prantslased ühestki eestlasest ja tema tegevusest Eestis niipalju pole kuulnud, kui Teist ja siis veel Martnast". Ka viimase rehabiliteerimist oli Pusta "täie jõuga ajanud" vaatamata sellele, et seejuures tema enda artiklit esile toodi. Üldse oli Pusta delegatsiooni ühtsust alati kaitsnud ning "Kulli vahejuhtumine oli meile siin vast veel valusam kui Teile Skandinavias". Pusta arvas ka, et oli olnud viga Kulli üksinda Stockholmi jätta. ${ }^{180}$

Omajagu peavalu õnnestus Keskülal tekitada ka Martnale. Juba 4. septembril oli Martna Piibule kirjutanud ja palunud igaks juhuks abi Šveitsi sõiduloa saamiseks, kuna "hr. Keskkülla Stokholmis meie vastu vaenulikult talitab". ${ }^{181}$ Veebruariks olid nii Kesküla kui ka Martna siiski Šveitsi jõudnud, viimane neist eesmärgiga osaleda rahvusvahelisel II Internatsionaali konverentsil (3.-10. veebruaril). Martna pidi seal Eesti küsimust tutvustama ning taotlema Sotsialistlikult Internatsionaalilt Eesti iseseisvuse tunnustamist.

6. veebruaril kirjutas Martna Poskale, et kohalik enamlaste suhtes sõbralik ajaleht Berner Tagwacht teda (Martnat) "tõukab ja nöökab”, et ta bolševik ei ole. Lisaks süüdistas leht Martnat selles, et ta osalenud koos Balti junkrutega Inglise karistusekspeditsiooni ettevalmistamises Eesti töörahva vastu ning avaldanud 13. märtsil Svenska Dagbladetis artikli, kus kiitis heaks Saksa okupatsioonipoliitika Eestis. Järgmisel päeval käis Martna lehe toimetaja Hans Vogeli jutul, kellelt kuulis, et artikli taga on Aleksander Kesküla, kelle tõlgetel Eesti ja Rootsi lehtedest süüdistused põhinevat. ${ }^{182}$

14. veebruaril kirjutas Martna vastulause, mida aga ei avaldatud. ${ }^{183}$ Kuna toimetuses oli kinnitatud, et teated põhinevad Eesti ja Rootsi ajalehtedel, palus Martna Oskar Kallasel ja Sven Backlundil endale vastavaid artikleid saata. 21. veebruaril kirjutas Martna ka Köstnerile, et kui Ajutine Valitsus ei soovi valeteadete ümberlükkamisega tegeleda, peaksid Eesti sotsiaaldemokraadid ise tegema Internatsionaalsele Büroole ettepaneku uurimist

\footnotetext{
180 ERA, f. 1627, n. 1, s. 30, 1. 1-8, Pusta Tõnissonile 6.1.1919.

181 ERA, f. 1583 , n. 1, s. 33, l. 236, Martna Piibule 4.9.1918.

182 Mihkel Martna, "1918-19 päevaraamatust", Mälestused iseseisvuse võitluspäevilt, II köide: Vabadussõda 1918-1920, Eesti Ajakirjanikkude Liidu toimetusel (Tallinn: Rahvaülikool, 1930) 334-335; ERA, f. 1619, n. 1, s. 32, 1. 2-4, Martna Poskale 6.2.1919; f. 1619, n. 1, s. 32, l. 10-13, "Zur Aufklärung" 14.2.1919; ibid., 1. 4-5, Martna Poskale, 8.2.1919.

183 ERA, f. 1619, n. 1, s. 32, 1. 13, “Zur Aufklärung” 14.2.1919.
} 
korraldada, et kindlaks teha, kas Eesti sotsiaaldemokraadid on tõepoolest "sotsialismuse äraandjad”, kes olid "ühes Vene tagurlastega ja baltisaksa junkrutega" Eesti proletariaadi vastu võõrväed maale kutsunud. ${ }^{184}$

Ka oma päevaraamatus kirjutab Martna, et ehkki artiklil konverentsi käigule nähtavat mõju ei olnud, olid Tagwachti teated talle siiski väga pahandavad. Kuulnud, et nende taga on Kesküla, võinud ta neid lihtsa laimuna hindama hakata, kuna "[k]ibedate kokkupõrgete pärast olin ma selle härra vihaalune”. ${ }^{185}$ Igatahes oli Keskülal õnnestusnud Eesti välisesindajaid jällegi provotseerida.

\section{Kesküla ja välisdelegatsioon: kokkuvõte ja järeldused}

Ehkki on tõenäoline, et Aleksander Kesküla tegevuse mõju Eesti diplomaatia ja välispoliitika väljakujunemisele pikemas perspektiivis oli väheoluline, mängis ta 1918. aastal Skandinaavias tegutsenud protodiplomaatilise välisesinduse jaoks siiski võrdlemisi olulist rolli. Eeskätt Kesküla head kontaktid Stockholmi Prantsuse saatkonnaga, kus ta esitles ennast Eesti Entente'i-sõbraliku patriootliku liikumise esindajana, võimaldasid tal pressiatašee André Waltzi kaudu avaldada Stockholmis viibivate välisesindajate tegevusele üsna suurt mõju, kujutades neid konkureeriva, saksasõbraliku voolu pooldajatena. Tulenevalt olukorrast, kus välismaal ei puudunud mitte ainult valmisolek Eesti Vabariiki de jure tunnustada, vaid usk Eesti riiklusesse üleüldse, ning sõdivad pooled suhtusid erinevatesse proto- ja paraesindustesse puhtpragmaatilistest kaalutlustest lähtuvalt, osutus orientatsiooniküsimus määravamaks kui ükskõik millised muud asjaolud. Kesküla, kes oli taolist mängu terve sõja vältel kaasa teinud, oskas prantslastele jätta endast mulje kui "õigema" orientatsiooni esindajast ning ametlikule välisdelegatsioonile seeläbi mitmesuguseid probleeme põhjustada, tõenäoliselt neid ka mitmel juhul otseselt provotseerides.

Tõnissoni ja Kesküla kohtumise ajal kristalliseerunud põhimõtteline vastuolu proto- ja paradiplomaatilise lähenemise vahel - kas Eesti diplomaatiat peaks ajama "ühenduses Eestiga" või mitte - muutis vanade vaenlaste edasise koostöö kiiresti võimatuks. Arvatavasti lisas õli tulle ka Tõnissoni hilisem soovimatus tunnustada Kesküla rolli esimese de facto tunnustuse saamisel Prantsusmaalt. Ilmselt kättemaksuks hakkas Kesküla saatkonna kaudu levitama jutte Martna ja Tõnissoni saksasõbralikkusest, mille kohta

184 ERA, f. 1619, n. 1, s. 32, l. 13a, Martna Kallasele 14.2.1919; ibid., l. 13b, Martna Backlundile 14.02.1919; ibid., l. 14-15, Martna Köstnerile 21.2.1919.

${ }^{185}$ Martna, "1918-19 päevaraamatust", 340. 
polnud raske sobivat tõendusmaterjali leida või fabritseerida. Kui peab paika, et Kesküla püüdis Entente’i-meelse Kulli kaudu välisesindusega siiski mingi kontakti luua, viis see katse igatahes vastupidise tulemuseni ning välisdelegatsioon esines hoopis avaliku Kesküla-vastase deklaratsiooniga. On põhjust uskuda Waltzi teadet, et Kesküla oli selle pärast "väga vihane".

Tõenäoliselt järgmine Kesküla samm oli Kullilt saatkonna kaudu Saksa okupatsiooni vastase protestiavalduse nõudmine, mille leige vastuvõtt teiste Skandinaavias viibivate delegatsiooniliikmete poolt viis juba tõsisemate vastuoludeni Kulli ja kopenhaagenlaste vahel. Kahtlustusi, et Kull oli Kesküla ja Waltzi lõksu langenud, Kull ise oma mälestustes mõistagi ei maini. Ent tõenäoliselt hakkas ta hiljemalt juulikuus ka ise uskuma väiteid Martna ja Tõnissoni saksasõbralikkuse kohta ning pidama oma Entente'i-meelsust viimastele vastukaaluks. Kuna Kull arvas enda orientatsiooni õigemaks, pahandasid teda seda sügavamalt Kopenhaagenis paikneva grupi ning seda juhtiva Tõnissoni domineerimispüüded.

Augusti alguse vaidlused kodukorra- ja orientatsiooniküsimustes süvendasid lõhet Kopenhaageni ja Stockholmi välissaadikute vahel veelgi. Tõenäoliselt aitas sellele kaasa ka asjaolu, et Kull oli saanud endale liitlase vahepeal Rootsi jõudnud, samuti rõhutatult saksavastase Suitsu näol. Septembrikuises kulleriafääris, kui Kesküla kasutas Tassa toodud teateid ära delegatsiooni provotseerimiseks, paistsid Kull ja Suits silma suhteliselt leebe suhtumisega Tassasse, jättes näiteks süü Afton-Tidningeni intervjuus täiesti Kesküla kaela. Juba sellest episoodist, mis kopenhaagenlaste poolt viis Tassa Saksa agendiks tembeldamiseni Briti saatkonnas, on näha, et välisdelegatsiooni juhatus oli hakanud järjest enam tegutsema Kulli ja Suitsu selja taga. Omalt poolt hakkasid Kull ja Suits jätma tähelepanuta järjest rohkem juhatuse juhtnööre, kuni selleni välja, et keeldusid tunnustamast ja levitamast nende meelest saksameelset "avalikku kirja".

Ehkki Kesküla oli septembris Rootsist lahkunud, oli ta Elevandi ja Waltzi kaudu väga tõenäoliselt ka edaspidi sündmustest hästi informeeritud. Pole võimatu, et Keskülal oli ka mingi otsesem roll välisdelegatsiooni lagunemisprotsessis, mis päädis Kulli väljaviskamise ja informatsioonibüroo sulgemisega. Eriti tõenäoline tundub, et Kulli ja Suitsu esilekutsutud lahtiütlemine "avalikust kirjast" Prantsuse laenu meelitusel, oli ettekavatsetud provokatsioon. Kuna sündmustele olid eelnenud Virgo sammud Kesküla vastu, võis taas olla tegemist kättemaksuga.

Samas oli Kulli kiires languses kindlasti süüdi eelkõige tema enda mõtlematu käitumine ning liigne toetumine Larkale, keda ta tegelikult ei tundnud. Ent vaevalt oleks Kull seda teed läinud, kui talle poleks selleks 
ajaks kõikide intriigide ja viperuste tagajärjel tundunud, et püha üritust tuleb kaitsta kõigi teiste vaenulike jõudude kõrval ka Rheinselskabeti enda eest. Kesküla mängis taolise arusaama väljakujundamises nii otseselt kui kaudselt üsna olulist osa, ehkki on tõenäoline, et ka muude väliste mõjurite puudumisel oleks juba ülitundlik orientatsiooniküsimus iseenesest nii või teisiti mingite vastuolude põhjustajaks osutunud.

Viimaks õnnestus Keskülal otseselt või kaudselt provotseerida välissaadikuid ka Pariisis ja Bernis. Esimesel juhul andis tema suvine tegevus hoogu Piibu ja Pusta tülile domineerimishimulise Tõnissoniga, mis ka sel juhul oleks kahtlemata selletagi pead tõstnud. Teisel juhul oskas Kesküla Šveitsis infosulus viibivale Martnale niisama suurt meelehärmi valmistada, ilma et sellel tõsisemaid tagajärgi oleks olnud.

Kokkuvõtteks: Ehkki Kesküla tegevus polnud Skandinaavia välisdelegatsiooni probleemide ainus ega isegi peamine põhjus, tõusid Kesküla intriigide tõttu tulid teravamalt esile isiklikud ja poliitilised vastuolud välisdelegatsiooni sees, seda eriti üksteisega teineteisega tihedalt seotud alluvussuheteja orientatsiooniküsimustes. 1918. aasta sügiseks oli Keskülast nii stockholmlaste kui ka kopenhaagenlaste jaoks kujunenud tont, mida keda otseselt või kaudselt teise poole tegevuse taga luuramas nähti. Juhtus sedagi, et välisdelegatsioon komplitseeris provokatsioonidele vastates avalikult oma olukorda, seda näiteks Virgo sõnavõtu näol Soome-Eesti uniooni poleemika käigus. Ent peamine mõju oli intriigidel siiski välisdelegatsiooni ühtsusele, mis sai 1918. aasta suvel ja sügisel kannatada kuni lagunemiseni välja.

Teisalt avaldas Kesküla juhtum välisdelegatsioonile teatud määral ka stimuleerivat mõju ning virgutas seda passiivsusest. Intriigid aitasid vähemalt kaudselt kaasa sellele, et delegatsioon üliolulisi kodukorra- ja orientatsiooniküsimust üldse lahendama hakkas.

Lõpuks illustreerib lugu laiemaltki, millised probleemid protodiplomaatilist välisdelegatsiooni kimbutasid. Vahest määravaima tähtsusega neist olid sidepidamisraskused kodumaaga ning see, et kuni 1918. aasta hilissügiseni ei viibinud välismaal ühtegi valitsuse liiget, kes oleks saanud operatiivsemalt tegutseda. Siis võinuks ära jääda kogu Kulli lahkumiseni viinud episood, sest Eesti rahvusväeosad Põhja-Venemaal olid juba nagunii asutatud. Ent oma rolli mängisid ka isiklikud ja maailmavaatelised vastuolud, volituste ähmasus ning eelkõige Eesti iseseisva riikluse ja selle välisesinduse esialgsus ja tundmatus, mida Kesküla kogenud poliitikuna enda huvides välisdelegatsiooni vastu edukalt ära kasutada oskas. 


\section{AвSTRACT: Intrigue, provocation, and the birth of independence: the Estonian foreign delegation and Aleksander Kesküla}

This article is an account of the relations between two groups working in Scandinavia in 1918 in order to attain foreign recognition of Estonian independence. The first of these was the official Estonian foreign delegation, headed by Jaan Tõnisson, which began its work in February 1918. The other group consisted for the most part of a single person: the emigré adventurer and self-styled politician Aleksander Kesküla who had been involved in quasi-diplomatic activities as a representative of Estonians since the beginning of the war. Due to the nature of the available sources, I am focusing on the delegation's viewpoint on the events described.

I have tried to frame the basic difference between the delegation and Kesküla with the help of the notions of proto-diplomacy and para-diplomacy, as they have been used by Ivo D. Duchacek and others. The identity of the delegation, a proto-diplomatic body, was that of a foreign representation of Estonian Maapäev (the first ever representative body of the Estonian people). The delegation members' mandates, however, were vague and of doubtful authority since Maapäev had been dissolved and Estonia had been occupied by German forces. This situation made it almost impossible to get up-to-date instructions from the nearly dysfunctional provisional government in Estonia. The members of the delegation, all inexperienced in diplomacy, were correspondingly prone to passivity and - if not - to missteps.

Kesküla as a para-diplomat was on the outside unconcerned with legalities and thought that his experience alone made him superior to his amateur colleagues, lack of mandate notwithstanding. Unlike the official delegation, he was well-connected and highly competent in the political affairs of Stockholm, which he could and would use against the delegation.

The conflict between the delegation and Kesküla grew out of personal animosities, as well as the basic incompatibility between their viewpoints: one proto- and the other para-diplomatic. It began with the total failure of negotiations between Kesküla and Tõnisson, and was cemented by the delegation's public declaration that Kesküla had no right to act as a representative of Estonians.

Kesküla's revenge was to spread rumors that some of the delegation members - particularly Jaan Tõnisson and Mihkel Martna, who also happened to be his personal enemies - were German-friendly, if not outright German agents. This could be "proved" in several ways: certainly by referring to their contacts with German ministers in Stockholm and 
Copenhagen, but also by raising suspicions of past contacts with German authorities. The intrigue was mostly arranged through the Embassy of France in Stockholm where Kesküla had good, long-term contacts with the minister Thiébaut and the "press attaché" André Waltz, and where he presented himself as the leader of an alternative, left-wing anti-German movement in Estonia. The first provisional de facto French recognition of the Estonian constitutive assembly, although sent to Tõnisson, had also been achieved at least partially thanks to Kesküla.

Kesküla's schemes had the effect of exacerbating already-existing personal and political animosities inside the delegation. The naturally domineering personality of Tõnisson was one source of tension, another one was the orientation controversy between German-friendly and Ententefriendly members of the delegation. The main rift appeared between the members situated in Copenhagen (Tõnisson, Martna, Karl Menning, and occasionally Eduard Virgo) and those in Stockholm (Ferdinand Kull and Gustav Suits). Kull in particular was apt to demand more decisive action against Germany and began to consider himself something of a counterbalance to the delegation's German-friendliness, which provoked him to act increasingly on his own volition and eventually caused his expulsion.

Any long-term effect of Kesküla's activities on the obtainment of Estonian independence and the development of Estonian statehood was probably negligible. All the same, the story illustrates well the problems facing the first Estonian diplomats, and their inherent vulnerability to intrigue and provocation. On a more positive note, the need to resist Kesküla's attacks also had the result of making the delegation tackle more decisively the delicate questions of its inner hierarchy, orientation vis à vis the belligerents and the overall course of action.

KeYwORDS: History of Estonia, First World War, Aleksander Kesküla, protodiplomacy.

Mart Kuldkepp (b. 1983), Ph.D. student, Assistant Lecturer at the Department of Scandinavian Studies, University of Tartu.*

\footnotetext{
* Correspondence: Mart Kuldkepp, Department of Scandinavian Studies, University of Tartu. Ülikooli 17, 51014, Tartu, Estonia. E-mail: mart.kuldkepp@ut.ee
} 